\title{
ARCHIWUM PARAFII LUBAWSKIEJ. INWENTARZ
}

\section{WSTĘP DO INWENTARZA}

Podstawową jednostką w administracji kościelnej jest parafia. Archiwum parafialne, którego zasób pokrywa się w zasadzie z zespołem, obejmuje akta wytworzone i zgromadzone przez urząd parafialny, którym kieruje proboszcz. Kościół od wieków gromadził dokumenty i przechowywał je w archiwach na wszystkich szczeblach swej organizacji. Ich właściwe urządzenie i ochronę obwarował przepisami, poczynając od średniowiecza ${ }^{1}$. Bardziej szczegółowe normy prawne w tym względzie wydał sobór trydencki (1545-1563) oraz potrydenckie polskie prawodawstwo partykularne. W nowszych czasach dla całego Kościoła przepisy regulujące organizację archiwów kościelnych sformułował zarówno Kodeks prawa kanonicznego z 1917 roku (kan. 470), jak również z 1983 roku (kan. 535)². Także synody diecezji chełmińskiej i pelplińskiej, w swych statutach uwzględniały prowadzenie archiwum parafialnego ${ }^{3}$.

* Ks. prof. dr hab. Anastazy Nadolny jest kierownikiem Zakładu Historii Kościoła w Czasach Nowożytnych Wydziału Teologicznego UMK i wykładowcą historii Kościoła w Wyższym Seminarium Duchownym w Pelplinie.

${ }^{1}$ W. Abraham, Ustawodawstwo kościelne o archiwach, "Archeion”, 4 (1928), s. 21-14.

${ }^{2}$ Ks. H. Misztal, Sytuacja prawna archiwum parafialnego, Archiwa, Biblioteki i Muzea Kościelne, (dalej: ABMK) 75 (2001), s. 77-90; ks. A. Weiss, Archiwa kościelne w "Codex iuris canonici” pap. Jana Pawła II, „Roczniki Teologiczno-Kanoniczne”, 31 (1984), z. 4, s. 115-124.

${ }^{3}$ Por. Constitutiones synodales necnon ordinations Dioecesis Culmensis a saeculo XV usque 
Ostatnio coraz bardziej zauważa się zainteresowanie także archiwami parafialnymi. Niewątpliwie wpływ na to ma podejmowanie prac nad monografiami parafii, miejscowości lub historii mniejszych regionów tzw. małych ojczyzn. Archiwa parafialne w większości do dziś pozostają nieuporządkowane, stąd wynikają trudności z ich wykorzystaniem, lub nawet niedostępność, przy czym nieraz giną co wartościowsze jednostki zabierane przez nieuczciwych kwerendzistów. Stąd rodzi się postulat ich naukowego opracowania i udostępniania. Najprostszym rozwiązaniem tego problemu byłoby przekazywanie zarchiwizowanej i niepotrzebnej już w bieżącej działalności parafii dokumentacji do archiwów diecezjalnych, gdzie przygotowani pracownicy mogliby je naukowo opracować. Dopiero ich zdeponowanie w centralnych archiwach kościelnych pozwoli na lepsze wykorzystanie informacji w nich zawartych. Przecież zawierają one w sobie wiele ciekawych materiałów historycznych, odnoszących się nie tylko do spraw kościelnych, duszpasterskich, odzwierciedlających i obrazujących życie tej podstawowej komórki Kościoła, lecz także luźniej związanych z nimi informacji, jak problemy szkolnictwa, kultury, demografii i kwestii społecznych, a nawet gospodarczych i politycznych. W wielu wypadkach pozwalają one także na uzupełnienie materiałów przechowywanych w archiwach państwowych, a nawet archiwach centralnych diecezjalnych, jak np. w Pelplinie, gdzie akta odnoszące się do parafii i personalne spaliły się w czasie drugiej wojny światowej. Zdeponowanie, zabezpieczenie i zinwentaryzowanie akt parafialnych $\mathrm{w}$ archiwach centralnych odciąży w jakimś stopniu proboszczów, a badaczom ułatwi zadanie. Znaczeniu archiwów parafialnych dla regionalnej historii kościelnej poświęcono we wrześniu 2000 roku w Ośrodku Archiwów, Bibliotek i Muzeów Kościelnych KUL sympozjum Problemy archiwów parafialnych i klasztornych ${ }^{4}$. Odpowiedzią na wysunięte wówczas postulaty niech będzie poniższy inwentarz Archiwum Parafii Lubawskiej, jednej z najstarszych i wiodących parafii dawnej diecezji chełmińskiej, obecnie zaś toruńskiej5.

ad XVII, ed. A. Mańkowski, „Fontes”, 24 (1929); Constitutiones synodales editae et promulgatae ab... Andrea Stanislao Comite in Zatuskie Zatuski... in dioecesana synodo celebranta in Ecclesia Archipresbyterali Lubaviensi diebus 16-18 mensis Septembris A.D. 1745, Brunsbergae 1746 (Caput: De officiis parochorum), s. 155; Statuta synodi dioecesanae Culmensis Pelplini ab Illmo ac Revmo D. Episcopo Stanislao W. Okoniewski habitae A.D. 1928 diebus 27-29 Decembris, Pelplini 1929, stat. 2 i 79; Statuty synodu diecezjalnego chetmińskiego odbytego w dniach 7-9 lipca 1959 roku w Pelplinie przez... ks. biskupa ordynariusza Kazimierza Józefa Kowalskiego, „Orędownik Diecezji Chełmińskiej", 10 (1959), stat. 79; Statuty I synodu diecezji pelplińskiej, Pelplin 2001, stat. 43.

${ }^{4}$ ABMK 75 (2001), s. 6-190.

${ }^{5}$ Już wcześniej opublikowałem inwentarze parafii św. Michała Arch. w GdyniOksywiu oraz Bożego Ciała i Wniebowzięcia NMP w Pelplinie, por. "Na początku było Oksywie”, pod red. J. Borzyszkowskiego, Pelplin 2004, s. 196-210; Parafia pelplińska i jej duszpasterze w XIX i XX wieku, pod red. J. Borzyszkowskiego, Gdańsk-Pelplin 2007, s. 197-228. 


\section{DZIEJE USTROJOWE TWÓRCY ZESPOŁU}

Lubawa - siedziba parafii lubawskiej w diecezji toruńskiej - jest miastem leżącym w południowo-zachodniej części województwa warmińsko-mazurskiego. Położona nad rzeczką Sandelą stanowi centrum ziemi lubawskiej, a także siedzibę dekanatu o tej samej nazwié ${ }^{6}$.

Miasto należy do najstarszych osad tego regionu. Chrześcijaństwo na ziemi lubawskiej wprowadzono w XIII wieku dzięki działalności cystersa Chrystiana, który nawrócił miejscowego wielmożę pruskiego Surwabuna. Ochrzcił go prawdopodobnie pap. Innocenty III w uroczystość Objawienia Pańskiego, 6 stycznia 1216 roku w Rzymie, a samego Chrystiana, w uznaniu zasług, wyświęcił na „biskupa Prus"7. Surwabuno, który na chrzcie otrzymał imię Paweł, podarował Lubawę Chrystianowi. Darowiznę potwierdził papież bullą wystawioną 18 lutego 1216 roku. Jest to zarazem pierwsza historyczna wzmianka o tej miejscowości. W dokumencie zapisano ją jako Lubovia ${ }^{8}$. Możliwe, że już wówczas powstała w Lubawie pierwsza parafia i wzniesiono drewniany kościół. Dalszą chrystianizację prowadzili biskupi chełmińscy.

Nazwa miasta jest pierwotna, o czym świadczą najstarsze przekazy historyczne z 1216 i 1243 roku9 ${ }^{9}$ W średniowieczu występowała ona w różnych odmianach, jak: Lubovia, Lubow, Lebaw, Lebe, Lobaw, Lobau, Lubaw. Dzisiejsza nazwa „Lubawa” po raz pierwszy pojawiła się w 1466 roku, a ustaliła się

${ }^{6}$ J. Śliwiński, Lubawa. Z dziejów miasta i okolic, Olsztyn 1982; tenże, Studia z dziejów Lubawy i okolic do 1939 roku, Olsztyn 1996; J. Falkowski, Ziemia Lubawska. Przyroda, historia, osadnictwo, społeczeństwo, gospodarka, Toruń 2006; G. Liek, Die Stadt Löbau in Westpreussen mit Brücksichtigung des Landes, Marienwerder 1892; ks. J. Fankidejski, Lubawa, w: Stownik geograficzny Królestwa Polskiego i innych krajów stowiańskich, t. 5, pod red. F. Sulimierskiego, B. Chlebowskiego, W. Walewskiego, Warszawa 1884, s. 384-392; M. Wrzeszcz, Lubawa, w: Encyklopedia katolicka, t. 11, Lublin 2006, s. 15-17; Diecezja toruńska. Historia i teraźniejszość, t. 11: Dekanat lubawski, pod red. ks. S. Kardasza, Torun 1995, s. 42-61.

${ }^{7}$ R. Grodecki, Chrystian, pierwszy biskup Prus (1216-1245), w: Polski stownik biograficzny, t. 3, Kraków 1937, s. 456-457; Cz. Deptuła, Chrystian SOCist., w: Encyklopedia katolicka, t. 3, Lublin 1979, s. 293; K. Zielińska-Melkowska, Święty Chrystian - cysters, misyjny biskup Prus i pasterz Ziemi Chetmińskiej w latach 1222-1245, „Przegląd Regionalny”, 1993, z. 7, s. 12-19 i „Nasza Przeszłość”, t. 83 (1994), s. 35-61, tamże literatura; J. Powierski, Chrystian bp pruski, w: Stownik biograficzny Pomorza Nadwiślańskiego, t. 1, pod red. S. Gierszewskiego, Gdańsk 1992, s. 214-216; J. Szews, Stownik biograficzny Ziemi Lubawskiej, t. 1, Lubawa 2000, s. 41; ks. A. Liedtke, Zarys dziejów diecezji chetmińskiej do 1945 roku, Pelplin 1994, s. 14.

${ }^{8}$ Bullarium Poloniae, t. 1, 1000-1342, ed. I. Sułkowska-Kuraś et S. Kuraś, Romae 1982, s. 28; Preußisches Urkundenbuch, Bd. 1, Königsberg 1882, nr 9.

${ }^{9}$ Urkundenbuch des Bisthums Culm, bearb. von C. P. Woelky, Bd. 1, Danzig 1884, s. 4, nr 9 (dalej: UBC); Bullarium, s. 28; Stownik historyczno-geograficzny Ziemi Chetmińskiej w średniowieczu, oprac. K. Porębska i M. Grzegorz, pod red. M. Biskupa, Wrocław 1971, s. 68. 
ostatecznie w XVII wieku; Niemcy używali określenia Löbau ${ }^{10}$. W herbie i na pieczęciach - jak wiele średniowiecznych miast - Lubawa nosiła wizerunek swego właściciela - biskupa chełmińskiego ${ }^{11}$.

Chrystian od 1216 roku był misyjnym biskupem Prus, dlatego - jeżeli już w tym czasie istniała parafia - podlegała jego jurysdykcji. Organizację kościelną na terenie Prus i ziemi chełmińskiej utworzono w 1243 roku dzięki zabiegom Krzyżaków. Lubawa od początku wchodziła w skład diecezji chełmińskiej. Biskupstwo to, razem z trzema tzw. diecezjami pruskimi, utworzył pap. Innocenty IV. Dekret, z jego polecenia, wystawił legat biskup Wilhelm z Modeny dnia 28 lipca 1243 roku $^{12}$. W skład diecezji chełmińskiej weszła ziemia chełmińska w granicach rzek Wisły, Drwęcy i Osy oraz ziemia lubawska, której terytorium określono w późniejszych układach między biskupami i władzami zakonu w latach 1254-1260, a ostatecznie w 1303 roku $^{13}$. Jako uposażenie biskup otrzymał 600 włók w ziemi chełmińskiej oraz jedną trzecią ziemi lubawskiej. Tę ostatnią część później znacznie powiększono, właścicielem połowy ziemi lubawskiej był bowiem książę łęczycko-kujawski Kazimierz. Aby uniknąć sporów z Krzyżakami, w 1257 roku podarował on ten obszar diecezji. Dlatego ostatecznie biskupi chełmińscy w ziemi lubawskiej posiadali pięć szóstych terytorium. Stanowiło ono podstawę dóbr stołowych biskupstwa (klucz lubawski) ${ }^{14}$. Sprawowali oni na nim władzę zwierzchnią, niezależną od Krzyżaków. Lubawę też obrali biskupi na jedną ze swych rezydencji i wybudowali zamek, zburzony po pierwszym rozbiorze Polski ${ }^{15}$. Ostatnim biskupem rezydującym w Lubawie był Andrzej Ignacy Baier (1759-1785). Z racji, że biskupi przeważnie mieszkali w Lubawie, odbyło się w niej kilka synodów diecezjalnych, m.in. w 1641 i 1745 roku. Również Kapituła Katedralna Chełmińska, powołana do życia 22 lipca 1251 roku przez pierwszego biskupa chełmińskiego Heidenryka (1245-1263), w ziemi lubawskiej otrzymała 300 włók ziemi, z ośrodkiem w Kurzętniku, jako część swego uposażenia ${ }^{16}$.

${ }^{10}$ Diecezja chetmińska. Zarys historyczno-statystyczny, Pelplin 1928, s. 440; J. Śliwiński, Lubawa, s. 47.

${ }^{11}$ M. Gumowski, Pieczęcie $i$ herby miast pomorskich, Toruń 1939, s. 110-113; J. Śliwiński, Lubawa, s. 47.

${ }^{12}$ A. Radzimiński, Wokót początków diecezji chetmińskiej, "Zapiski Historyczne”, 61 (1996), z. 2-3, s. 9-11; A. Liedtke, Zarys dziejów, s. 22; B. Kumor, Chetmińska diecezja, w: Encyklopedia katolicka, t. 3, Lublin 1979, s. 113-123; UBC, s. 4, nr 9.

${ }^{13}$ Ks. A. Nadolny, Granice diecezji chetmińskiej, „Studia Pelplińskie”, 16 (1985), s. 15-18; Stownik historyczno-geograficzny, s. 69.

${ }^{14}$ M. Biskup, Przemiany terytorialne diecezji chetmińskiej 1243-1992, w: Ars sacra, Toruń 1993, s. 13; S. Cackowski, Gospodarstwo wiejskie w dobrach biskupstwa i kapituty chetmińskiej w XVII-XVIII, cz. 1-2, Toruń 1961-1963.

${ }^{15}$ Por. Zamek w Lubawie dawniej $i$ dziś, pod red. L. Kajzera, Lubawa 2001.

${ }^{16}$ J. Hoelge, Das Culmer Domkapitel zu Culmsee im Mittelalter, "Mitteilungen der Literarischen Gesellschaft Masovia", 8 (1913), s. 134-161; 19 (1914), s. 116-148; A. Mańkowski, 
W ramach diecezji chełmińskiej Lubawa pozostała do 1992 roku. Na mocy bulli pap. Jana Pawła II Totus tuus Poloniae populus z 25 marca 1992 roku weszła w skład nowo utworzonej diecezji toruńskiej ${ }^{17}$.

Pod względem politycznym ziemia lubawska należała do państwa Prusów, zamieszkiwał ją szczep Sasinów. Od zajęcia tych terenów przez Krzyżaków (po 1230) do II pokoju toruńskiego (1466) wchodziła w skład państwa krzyżackiego, następnie do pierwszego rozbioru Polski znajdowała się w Królestwie Polskim, w prowincji Prusy Królewskie (woj. chełmińskie). Po pierwszym rozbiorze włączono ją do prowincji Prusy Zachodnie. Od pokoju w Tylży w 1807 roku weszła w skład Księstwa Warszawskiego, będąc w powiecie michałowskim, departamencie bydgoskim ${ }^{18}$. Po kongresie wiedeńskim 1815 roku ponownie znalazła się w Prusach, w regencji kwidzyńskiej, w utworzonym wówczas powiecie lubawskim, w prowincji Prusy Zachodnie i pozostawała w nich do zakończenia pierwszej wojny światowej, a ściślej do 19 stycznia 1920 roku, kiedy wkroczyło do niej polskie wojsko. Pod zaborem pruskim Lubawa stanowiła bastion polskości. W okresie międzywojennym miasto znajdowało się w woj. pomorskim ze stolicą w Toruniu, w powiecie lubawskim, którego siedzibę przeniesiono jednak do Nowego Miasta Lubawskiego ${ }^{19}$. Po wybuchu drugiej wojny światowej ziemia lubawska, jako terytoriom przygraniczne, już 1 września została zajęta przez wojska niemieckie. Włączono ją wówczas do prowincji nazwanej Okręgiem Rzeszy Gdańsk-Prusy Zachodnie. Na żądanie władz okupacyjnych administrator apostolski diecezji chełmińskiej, biskup Karol Maria Splett, zniósł podział na dekanaty i utworzył komisariaty, których granice pokrywały się z powiatami. Lubawa należała do powiatu (komisariatu) nowomiejskiego. Wojska radzieckie wkroczyły do Lubawy 21 stycznia 1945 roku, paląc miasto w 80 procentach. Po wojnie włączono ją do woj. olsztyńskiego. Od 1975 roku jest siedzibą gminy. W 1999 roku weszła w skład woj. warmińsko-mazurskiego, pow. Iława. Wszelkie zmiany polityczne znalazły odbicie w języku akt omawianego zespołu, a częściowo także w treści (stosunki z władzami państwowymi) ${ }^{20}$.

Kapituta Katedralna Chetmińska od 1466 do 1821, "Zapiski Towarzystwa Naukowego w Toruniu", 5 (1921), nr 5-6, s. 74-99; nr 7, s. 105-129; UBC, nr 29, s. 16-18.

${ }^{17}$ Tekst bulli zob. „Toruńskie Wiadomości Kościelne”, 1 (1992), nr 1-5, s. 5-16 i „Miesięcznik Diecezji Pelplińskiej”, 1 (1992), z. 2, s. 3-15.

${ }^{18} \mathrm{~W}$ zespole archiwum parafialnego zachowały się $\mathrm{z}$ tego okresu rozporządzenia władz państwowych (sygn. 9-9a) oraz akta urzędu stanu cywilnego, którego kierownikiem był miejscowy proboszcz (sygn. 111-123).

${ }^{19}$ A. Korecki, Lubawa 19 lat wolności 1920-1939, Lubawa 2000.

${ }^{20}$ J. Śliwiński, Lubawa, s. 20-245; M. Biskup, Dzieje diecezji chetmińskiej 1243-1992, w: Diecezja toruńska. Historia i teraźniejszość, t. 1, pod red. ks. S. Kardasza, Toruń 1994, s. 31; Dzieje Pomorza Nadwiślańskiego od VII wieku do 1945 roku, pod red. W. Odyńca, Gdańsk 1978; Historia Pomorza, t. 1-3, pod red. G. Labudy, Poznań 1969-1996. 
Na pojęcie parafii składa się kilka elementów. Dawne prawo kościelne, także Kodeks prawa kanonicznego z 1917 roku (kan. 216), jako główne elementy parafii wymieniało terytorium, ludność, duszpasterza i uposażenie. Kodeks pap. Jana Pawła II położył raczej nacisk na wspólnotę parafialną i duszpasterstwo prowadzone, pod władzą biskupa, przez proboszcza (kan. 515). Tutaj uwzględnić należy wszystkie te czynniki, jako że parafia rozwijała się w różnych okresach, a jej działalność znalazła odbicie w aktach omawianego zespołu. Ks. Stanisław Kujot jest zdania, że parafię - ośrodek kultu - w Lubawie utworzył biskup Chrystian ok. 1215 roku i że była to jedyna na tym terenie parafia przed utworzeniem diecezji chełmińskiej ${ }^{21}$. Jednak ośrodek ten został zniszczony w czasie powstania pruskiego w 1269 roku i trzeba było go ponownie lokować, a także odbudować zniszczone pierwociny kultury chrześcijańskiej i organizacji parafialnej. Dokonał tego biskup Herman (1303-1311), lecz przywilej jego zaginął. Zachował się tylko dokument biskupa Ottona (1324-1349) wystawiony na zamku lubawskim 13 kwietnia 1326 roku. Przy jego spisywaniu był obecny m.in. Jan, pleban lubawski ${ }^{22}$. Parafia była więc już w tym czasie od dawna zorganizowana. Prawdopodobnie w połowie XIV wieku utworzono dekanat lubawski, zwany wówczas archiprezbiteratem. Najstarsze wzmianki o dekanatach pojawiają się w latach 1330-1338. Na początku XV wieku biskup Arnold Stapil (1402-1416), w związku z synodem, wymienił Jana archiprezbitera i plebana lubawskiego ${ }^{23}$. Pierwszy jednak pełny spis dekanatów (archiprezbiteratów) pochodzi dopiero z 1641 roku i zamieszczony został w statutach synodu odprawionego 12 czerwca tego roku w Lubawie. Synod wyliczył w diecezji chełmińskiej 12 dekanatów. Dekanat lubawski tworzyło wówczas 12 parafii: Lubawa, Byszwałd, Grabowo, Grodziczno, Kazanice, Prątnica, Rożental, Rumian, Sampława, Złotowo i Zwiniarz oraz Turowo leżące w Prusach Książęcych ${ }^{24}$. Parafia Byszwałd od 1641 roku stała się filią Kazanic, a Złotowo w latach 1641-1910 było filią Lubawy ${ }^{25}$. Turowo w 1861 roku włączono do dekanatu pomezańskiego. W XIX i XX wieku do dekanatu weszły nowo utworzone parafie w Iławie (1860) i Suszu (1904) oraz lokalny wikariat w Glaznotach (1904). Po zakończeniu pierwszej wojny światowej i wytyczeniu przez traktat wersalski granicy polsko-niemieckiej

${ }^{21}$ Ks. S. Kujot, Kto zatożyt parafie w dzisiejszej diecezji chetmińskiej, „Roczniki Towarzystwa Naukowego w Toruniu", 12 (1905), s. 243 i 261; W. Rozynkowski, Powstanie i rozwój sieci parafialnej w diecezji chetmińskiej w czasach panowania zakonu krzyżackiego, Toruń 2000, s. 61-62.

${ }^{22}$ UBC, nr 217, s. 155-156.

${ }^{23}$ W. Rozynkowski, Uwagi o początkach organizacji archiprezbiteralnej (dekanalnej) na terenie diecezji chetmińskiej, „Studia Pelplińskie”, 27 (1998), s. 317.

${ }^{24}$ Constitutiones synodales necnon ordinations dioecesis Culmensis a saec. XV usque ad XVII, ed. A. Mańkowski, „Fontes”, 24 (1929), s. 48.

${ }^{25}$ APL, sygn. 338-353. 
w Niemczech zostały Iława, Susz i Glaznoty, natomiast parafię w Koszelewach, dotąd pozostającą $\mathrm{w}$ dekanacie pomezańskim, który również wcielono do Niemiec, włączono do dekanatu lubawskiego. Jako ostatnia, w interesującym nas okresie, powstała parafia w Rybnie $(1928)^{26}$. Dalsze zmiany granic dekanatu lubawskiego nastąpiły w 1981 i 2002 roku, co było niewątpliwie podyktowane nowymi potrzebami duszpasterskimi ${ }^{27}$.

Terytorium parafii, oprócz Lubawy, obejmowało miejscowości: Fijewo, Lipy, Losy, Mortęgi, Targowisko i Tuszewo. W 2000 roku utworzono w Lubawie drugą parafię pw. św. Jana Chrzciciela i św. Michała Archanioła; włączono do niej Fijewo, Mortęgi i Tuszewo ${ }^{28}$.

Kościoły i kaplice. Kościół parafialny nosił nazwę św. Anny (wizytacja 1647), chociaż wizytator, kan. Jan Strzesz, około 1671 roku napisal, iż jedni przypisuja patronat Matce Boskiej, inni św. Annie ${ }^{29}$. W aktach prezentowanego zespołu występuje wezwanie św. Anny. Od 1958 roku w schematyzmach diecezjalnych pojawiła się nazwa Nawiedzenia NMP i św. Anny i tak jest do dzisiaj. Obecny kościół murowany w stylu gotyckim pochodzi z około 1330 roku, z późniejszymi przebudowaniami.

Na terenie parafii ponadto wzniesiono kilka kościołów i kaplic, a mianowicie kościół filialny św. Barbary (szpitalny) ufundowany przez biskupa Mikołaja Chrapickiego w 1500 roku, po pożarach odbudowany w 1779 roku. Kościół św. Jana, poklasztorny, w latach 1821-1945 służył protestantom, natomiast w zabudowaniach dawnego konwentu umieszczono szkołę; kościół w 1976 roku zamieniono na szkolny, a od 2000 roku stał się parafialnym. Kościół filialny Nawiedzenia NMP w Lipach - sanktuarium maryjne ziemi lubawskiej. Kościół filialny Wniebowstąpienia Pańskiego w Mortęgach poświęcony w grudniu 1982 roku. Kaplica pw. św. Jerzego (Sióstr Miłosierdzia) w szpitalu ${ }^{30}$.

${ }^{26}$ Schematismus des Bistums Culm mit dem Bischofssitze in Pelplin 1904, Pelplin 1904, s. XVI-XIX, 246-271, 375-408; ks. A. Nadolny, Granice, s. 21-23; ks. B. Tułodziecki, Dzieje parafii Najśw. Serca P. Jezusa w Rybnie, Pelplin 1993 (maszynopis w Bibliotece WSD Pelplin).

${ }^{27}$ Bp M. Przykucki, Dekret dotyczacy nowego podziatu administracyjnego diecezji chetmińskiej na dekanaty, „Orędownik Diecezji Chełmińskiej”, 32 (1981), s. 417-422; Bp A. Suski, Dekret w sprawie podziału administracyjnego diecezji toruńskiej na dekanaty, „Toruńskie Wiadomości Kościelne" 10 (2001), nr 3-4, s. 84-87; Diecezja toruńska. Spis parafii i duchowieństwa, Toruń 2002, s. 393-401. Por. W. Nawrocka, Ustrój i organizacja diecezji toruńskiej w latach 1992-2006, Torun 2007, s. 113-146 (maszynopis).

${ }^{28}$ Schematyzmy diecezjalne chełmińskie 1848 , s. 45,1904 , s. 261,1928 , s. 445,1975 , s. 157,1992, s. 178 , i toruński 2002 , s. 398-401.

${ }^{29}$ W. Rozynkowski, Święta Anna patronka najstarszych kościołów parafialnych Ziemi Chetmińskiej i Lubawskiej, „Roczniki Humanistyczne” 48 (2000), z. 4, s. 489-500.

${ }^{30}$ Diecezja chetmińska, s. 441; Diecezja toruńska, t. 11: Dekanat lubawski, s. 42-61; Diecezja toruńska 2005, s. 242-244; ks. Z. Gutowski, Matka Boska Lipska Patronka Ziemi Lubawskiej, Lubawa 1985; ks. K. Rynkowski, Sanktuarium Matki Boskiej Lipskiej w Lipach k. Lu- 
Kaplice dawniejsze nieistniejące: kaplica św. Barbary, kaplica na zamku lubawskim, kaplica św. Walentego w szpitalu - domu ubogich w Fijewie, kaplica na zamku w Mortęgach ${ }^{31}$.

Zakony. Franciszkanie sprowadzeni zostali z Saksonii przez biskupa Mikołaja Chrapickiego w 1502 roku. Po rozwiązaniu się konwentu w czasie reformacji biskup Piotr Kostka osiedlił ich w 1580 roku w klasztorze Bernardynów, którzy mieszkali w nim do kasaty w 1821 roku ${ }^{32}$. Siostry Miłosierdzia św. Wincentego à Paulo w 1861 roku osiedliły się przy szpitalu św. Jerzego, ponadto prowadziły dom starców, dom dziecka i przedszkole.

Szpitale. Szpital św. Jerzego został założony prawdopodobnie równocześnie z miastem i kościołem parafialnym. Szpital św. Walentego jest fundacją biskupa Jana Kuczborskiego z 1616 roku (statut 1865) (33. $^{33}$

Bractwa i stowarzyszenia. Podobnie jak w innych parafiach, również w Lubawie istniało wiele organizacji zrzeszających parafian, m.in.: Bractwo św. Anny (od 1604) i Bractwo Niepokalanego Poczęcia NMP (1672) - obydwa przy kościele Ojców Bernardynów, Bractwo Bożego Ciała (1608), Bractwo św. Antoniego Padewskiego (1695), Bractwo Różańcowe (1723), Bractwo Aniołów Stróżów (od 1798), Papieskie Dzieło Rozkrzewiania Wiary (1844), Bractwo Trzeźwości (1855), Stowarzyszenie św. Bonifacego i św. Wojciecha (1859), Bractwo św. Rodziny (1894), Sodalicja Mariańska (1898), Stowarzyszenie Młodzieży Katolickiej, Stowarzyszenie Czeladzi Katolickiej, Towarzystwo Ludowe, Liga Katolicka, Dzieci Maryi, Stowarzyszenie Pań Miłosierdzia św. Wincentego à Paulo, Apostolstwo Modlitwy, Bractwo Straży Honorowej Najśw. Serca P. Jezusa, Krucjata Eucharystyczna, Stowarzyszenie Dzieciątka Jezus ${ }^{34}$.

Odpusty w kościele parafialnym świętowano w dniu św. Anny (26 lipca) oraz Nawiedzenia NMP w Lipach (1-2 lipca), dawniej także Aniołów Stróżów.

Szkolnictwo. Szkoła parafialna zapewne istniała już w średniowieczu, choć pierwsza wzmianka o niej pochodzi z 1508 roku. W drugiej połowie XVII wieku istniała szkoła murowana, w której uczyło dwóch lub trzech nauczycieli. Po pierwszym rozbiorze szkolnictwo rozwijało się nadal, choć było już kontrolowane przez państwo. W 1864 roku otwarto szkołę dla dziewcząt, w 1873 roku progimnazjum, a rok później ewangelickie seminarium nauczycielskie. W 1935 roku Lubawa otrzymała gimnazjum. W zespole akt parafialnych dokumentacja

bawy, Pelplin 2000; ks. M. Rozmarynowicz, Sanktuarium Matki Boskiej Lipskiej w Lubawie, Pelplin 1991.

${ }^{31}$ Ks. J. Fankidejski, Utracone kościoły i kaplice w dzisiejszej diecezji chetmińskiej, Pelplin 1880, s. 127-130; Diecezja chetmińska, s. 443.

${ }^{32} \mathrm{Ks}$. T. Glemma, Odnowienie klasztoru bernardyńskiego w Lubawie przez biskupa chetmińskiego Piotra Kostkę, "Zapiski Historyczne” 62 (1997), z. 4, s. 113-124.

${ }^{33}$ Diecezja chetmińska, s. 444.

${ }^{34}$ Tamże. Por. sygn. 80-105. 
szkolna zachowała się prawie wyłącznie z okresu pruskiego, tylko dwie jednostki zawierają informacje odnoszące się do okresu międzywojennego ${ }^{35}$.

Proboszczowie. Twórcami zespołu akt parafialnych byli proboszczowie lubawscy. W czasach nowożytnych (XVIII-XX wiek), które dokumentują prezentowane akta, parafią tą zarządzali następujący proboszczowie ${ }^{36}$ : Jan Pacałowski (ok. 1730-1765), Zaleski (ok. 1775), Antoni Żurkałowski (1778-1783), Andrzej Fox (1783-1796), Piotr Tyblewski (1797-1805), Mateusz Tyblewski (1805-1843), Antoni Klingenberg (1843-1869), Dawid Sartowski (1869-1895), Aleksy Okoniewski (1895-1910), Leon Kasyna (1910-1942), Jan Manthey adm. in temp. i Jan Hildebrandt adm in spirit. (1942-1945), Edward Jankowski (1945-1946), Alfons Sylka (1946-1973), Bernard Kwiatkowski (1973-1986), Franciszek Koska (1986-1990) i Mieczysław Rozmarynowicz (od 1990).

\section{DZIEJE ZESPOłU ARCHIWALNEGO}

Akta parafii lubawskiej od momentu ich wytworzenia przechowywane były $\mathrm{w}$ archiwum parafialnym mieszczącym się $\mathrm{w}$ plebanii. Znajdujące się na niektórych teczkach wypustki i sygnatury świadczą o próbie ich porządkowania, czy raczej nadania miejsca $\mathrm{w}$ registraturze. Odnosi się to jednak tylko do akt wytworzonych w XIX i na początku XX wieku, co zaznaczono w inwentarzu. W zespole znajduje się kilka teczek innej proweniencji (magistrat miasta Lubawy, adwokatura, notariusz), które włączono do niego ze względu na zawartą w nich treść tyczącą się parafii. Nic nie wiadomo o innych sukcesjach. Nie sposób jednak ustalić jego kompletności. Większość akt jednak zachowała się, mimo że plebania spłonęła w styczniu 1945 roku. W 1993 roku ks. proboszcz Mieczysław Rozmarynowicz zdeponował je w Archiwum Diecezjalnym w Pelplinie, gdzie zostały uporządkowane i zinwentaryzowane. Przewiduje się ich przekazanie do Archiwum Diecezjalnego w Toruniu jako właściwego terytorialnie, gdyż od 1992 roku Lubawa weszła w skład diecezji toruńskiej.

\section{CHARAKTERYSTYKA ARCHIWALNA ZESPOŁU}

Tytuł: Akta Parafii Lubawskiej (APL). W czasach zaboru nazwa niemiecka: Acta der katholischen Pfarrkirche Loebau.

${ }^{35}$ Sygn. 127-144. Por. Diecezja chetmińska, s. 445; A. Korecki, Liceum lubawskie 1873-1998, Lubawa 1998.

${ }^{36}$ Wykaz lubawskich proboszczów, od średniowiecza do 1892 roku, podaje G. Liek (Die Stadt Löbau, s. 447-449), katalog proboszczów z okresu 1805-1942 opracował ks. H. Mross (Stownik biograficzny kaptanów diecezji chetmińskiej wyświęconych w latach 1821-1939, Pelplin 1995, s. 417). Biogramy niektórych rządców parafii zaprezentował J. Szews w Stowniku biograficznym ziemi lubawskiej, t. 1-3, Lubawa 2000-2008. 
Chronologia: XVIII-XX wiek.

Terytorium: Parafia Lubawa.

Rozmiar: 5 mb., 365 j.a. z sygn. 1-361 (cfr. sygn. 9a, 30a, 35a, 144a).

Typ kancelarii: Akta prowadzono systemem kancelarii spraw, charakterystycznym dla XIX-wiecznej kancelarii pruskiej, później także polskiej, jedynie wcześniejsze księgi dochodów i rozchodów oraz księgi brackie należy umieścić w okresie księgi wpisów. System bezdziennikowy.

Stan zachowania: Akta zachowały się na ogół w dobrym stanie. Zespół nie jest kompletny, o czym można się przekonać, analizując spis akt zamieszczony w inwentarzu z 1889 roku $^{37}$, ponadto brak jest odpisów dawnych wizytacji biskupich, istniejących jeszcze przed wojną ${ }^{38}$, a ogłoszenia parafialne (publicanda), niezmiernie ważne źródło do poznania dziejów parafii, zwłaszcza jej duszpasterstwa, zachowały się tylko z lat 1926-1929 i 1932-193739. Nawet w nowszych czasach odnotować można pewne ubytki, porównując aktualny stan z inwentarzem sporządzonym w 1972 roku $^{40}$. Ogólnie, akta parafialne nie sięgają poza rok 1778 , z kilkoma wyjątkami ${ }^{41}$. Niewątpliwie w archiwum parafialnym już od średniowiecza gromadzono napływającą dokumentację, jednak nie zachowała się ona do naszych czasów. Prawdopodobnie padła pastwą płomieni wielu pożarów, jakie nawiedziły miasto (1533, 1724, 1778). Najliczniej zachowały się akta XIX-wieczne. Wiek ten był sprzyjający działalności aktotwórczej, wówczas też duszpasterze wykazywali więcej zrozumienia dla wytworzonej przez siebie dokumentacji, a także troski o jej zachowanie. Było to niewątpliwie wynikiem większej kontroli ze strony władz, które wydały specjalne instrukcje o prowadzeniu archiwum, a przy tzw. tradycji urzędu proboszczowskiego sporządzano protokoły zawierające m.in. wykazy akt ${ }^{42}$. W seminarium duchownym uczono prac kancelaryjnych. Większość jednostek ma formę poszytu, typowego dla systemu kancelarii pruskiej XIX wieku. Poszyty posiadają nadruki, względnie ręczne napisy (tytuły), sygnatury registraturalne złożone z łacińskiej litery i numeru oraz często wypustki z nazwą jednostki. Po 1920 roku dokumentację umieszczano najczęściej w skoroszytach, a luzy

${ }^{37}$ Sygn. 16, k. 33-38.

${ }^{38}$ Diecezja chetmińska, s. 442.

${ }^{39}$ Sygn. 69-71.

${ }^{40}$ ADP, Inwentarze archiwów parafialnych z 1972 roku.

${ }^{41}$ Sygn. 15, 39, 94.

${ }^{42}$ Por. Instrukcya dla wszystkich proboszczów, administratorów probostw i dozorców kościołów $i$ innych fundacyi dotycząca się zarzadzania $i$ dozorowania majątków kościelnych..., jako też sktadania rachunków z tegoż w diecezyi chetmińskiej wydana dnia 29 października 1850 roku, Chełmno 1852 (druk, por. sygn. 11); Das Verfahren bei der Uebergabe von Pfarreien, Kirchen und Pfarr-Archiv, [w:] Sammlung kirchlicher Verordnungen, Erlasse und Dekrete für die Diöcese Culm, Bd. 1, Pelplin 1872, s. 17-25; Verfügung von 22. April 1885 betr. die Aufbewahrung des Pfarrarchivs, w: Sammlung kirchlscher Verordnungen, Bd. 2, Pelplin 1888, s. 121-122. 
w teczkach. W XIX wieku przeważał język niemiecki, choć zdarzają się pisma w językach polskim i łacińskim, po 1920 roku dominuje język polski. Jest kilkanaście ksiąg oprawnych. Są to głównie dzienniki dochodów i rozchodów, a także księgi brackie. Wśród innych form archiwalnych zachowały się mapy, rysunki techniczne, papiery wartościowe, plany.

Ponadto w zespole znajdowały się księgi liturgiczne (mszały, rytuały, lekcjonarze) i homiletyczne, w tym sześć starodruków. Wyłączono je i przekazano do Biblioteki Wyższego Seminarium Duchownego w Toruniu ${ }^{43}$.

\section{METODA PORZĄDKOWANIA ZESPOŁU}

Przekazane do archiwum akta parafialne były wymieszane z dziekańskimi dekanatu lubawskiego, w pierwszym więc etapie ustalono ich przynależność zespołową ${ }^{44}$ Ponieważ nie jest możliwe odtworzenie układu akt, jaki posiadały one w registraturze, $\mathrm{z}$ powodu braku znaków kancelaryjnych i zmieniających się systemów kancelarii, dlatego w trakcie inwentaryzacji zespołu nadano mu strukturę własną, kierując się kryterium treści i zasadą schematyczno-rzeczową, jako najbardziej celową w tym wypadku. W trakcie porządkowania akt bardziej zniszczone jednostki, względnie akta luźne, umieszczono w teczkach. Akta zostały ułożone w serie i podserie. Poszyty i teczki otrzymały tytuły, jeśli ich nie było, karty inwentarzowe, daty skrajne, naklejki z nadrukiem nazwy zespołu, sygnaturę ciągłą cyfr arabskich dla całego zespołu i paginację. Ponieważ już po zakończeniu prac porządkowych i nadaniu sygnatur dołączono jeszcze kilka jednostek, włączono je w odpowiednie miejsca, dając im sygnatury liczbowo-literowe. W sumie zespół liczy 365 jednostek archiwalnych. Akt nie brakowano. Porządkowali je Katarzyna Jeszke i ks. Dariusz Aniołkowski, w ramach praktyk wakacyjnych.

Każdy zapis inwentarzowy zawiera następujące elementy: 1/ sygnaturę, 2/ tytuł jednostki, opis zewnętrzny, język dokumentacji, liczbę kart oraz sygnaturę registraturalną (o ile taka się zachowała), 3/ daty skrajne.

\section{ZAWARTOŚĆ ZESPOŁU}

Na treść zespołu składają się akta związane z funkcjonowaniem parafii lubawskiej, którym $\mathrm{w}$ trakcie inwentaryzacji nadano następujący układ:

${ }^{43}$ Por. Protokół przekazania do Biblioteki Wyższego Seminarium Duchownego w Toruniu ksiąg wyłączonych z zespołu Archiwum Parafii Lubawskiej, z dnia 25 III 2008, L.dz. 61/08/A.

${ }^{44}$ Ks. A. Nadolny, Archiwum dziekańskie dekanatu lubawskiego, „Teologia i Człowiek” 7-8 (2006), s. 173-184. 
I. Duchowieństwo (sygn. 1-3), II. Przedstawicielstwa parafialne (sygn. 4-8), III. Rozporządzenia władz kościelnych i państwowych (sygn. 9-14), IV. Kościół i budynki parafialne (sygn. 15-38), V. Kościoły i kaplice na terenie parafii (sygn. 39-61), VI. Duszpasterstwo. Służba Boża. Sakramenty (sygn. 62-79), VII. Bractwa i stowarzyszenia kościelne (sygn. 80-105), VIII. Statystyka ludnościowa (sygn. 106-123), IX. Stosunki wyznaniowe (sygn. 124-136), X. Szkolnictwo (sygn. 127-144a), XI. Szpitale (sygn. 145-176), XII. Fundacje i legaty (sygn. 177-240), XIII. Sprawy gospodarczo-finansowe (sygn. 241-316), XIV. Sprawy sporne - procesy (sygn. 317-339), XV. Kościół parafialny (filia Lubawy) w Złotowie (sygn. 340-355), XVI. Varia (sygn. 356-361).

Zespół nie posiada ksiąg metrykalnych - chrztów, małżeństw i zgonów. Jednak celowe będzie tu poświęcenie kilku zdań tej dokumentacji w związku z jej podstawowym znaczeniem dla badań demograficznych i genealogicznych. Zgodnie z nakazem soboru trydenckiego (1545-1563), w parafiach zapoczątkowano prowadzenie ksiąg metrykalnych chrztów i zawartych małżeństw, nieco później także zgonów. Wizytator biskupa Andrzeja Olszowskiego, kan. Jan Ludwik Strzesz, ok. 1671 roku odnotował w Lubawie księgi chrztów i ślubów zaczynające się od 1581 roku, natomiast księgę zgonów założył prob. Walenty Gillius w 1666 roku $^{45}$. Prawdopodobnie spłonęły one w czasie pożaru w 1778 roku, bowiem w 1928 roku istniała tam już dokumentacja tylko od tego roku ${ }^{46}$. W czasie drugiej wojny światowej lubawskie księgi metrykalne z lat 1778-1874 zostały wywiezione do Niemiec i zgromadzone w Biskupim Archiwum Centralnym w Ratyzbonie, gdzie poddano je udanej konserwacji. W 2002 roku wróciły do Polski i zostały zdeponowane w Archiwum Diecezjalnym (Archiwum Akt Dawnych) w Toruniu, w osobnej kolekcji. Znalazły się w niej następujące księgi: chrzty 1780-1874, małżeństwa 1778-1874, zgony 1824-1875. Nowsza dokumentacja nadal pozostaje w kancelarii parafialnej.

\section{ARCHIVE OF THE LUBAWA PARISH}

\section{SUMMARY}

Lubawa - the center of the Lubawa Land and the seat of the decanate is counted among the oldest parishes in this district. For centuries it belonged to the Chelmno diocese, set up on July 28, 1243, and from March 25, 1992 it entered into the composition of the Torun diocese. The archival fund, presented by the published inventory, has been created by the parish priests of Lubawa. It counts 365 archive units and it contains records which concern the history of the parish since the half of the $18^{\text {th }}$ century. Only some units have elder provenience (records of incomes and books of church fraternities).

${ }^{45}$ Visitationes Episcopatus Culemnsis Andrea Olszowski episcopo a. 1667-72 factae, curavit

B. Czapla, „Fontes” 7 (1903), s. 348.

${ }^{46}$ Diecezja chetmińska, s. 442. 
The elder records probably fell a prey to fires, which several times afflicted the town. Although the archival fund did not remain as a whole, it makes however a valuable material that documents the history of the parish in the modern times.

\section{INWENTARZ}

\begin{tabular}{|c|c|c|}
\hline Sygn. & Tytuł jednostki & Daty \\
\hline & I. Duchowieństwo & \\
\hline 1 & Księża wikariusze. Akta betreffend Vikare. (Poszyt, j. pol., niem., k. 22) & $1932-1942$ \\
\hline 2 & $\begin{array}{l}\text { Missionspriester. Congregation de la Mission de St. Lazare Paris. } \\
\text { (Poszyt, j. pol., niem., tac., franc., k. 28) }\end{array}$ & $1863-1864$ \\
\hline \multirow[t]{2}{*}{3} & $\begin{array}{l}\text { Landesausweisung des Geistlichen [HipolitusValent.] Żmijewski in Bischwalde. } \\
\text { (Poszyt, j. niem., k 36; registr. K22) }\end{array}$ & $1865-1887$ \\
\hline & $\begin{array}{c}\text { II. Przedstawicielstwa parafialne - Reprezentacja Gminy Parafialnej, } \\
\text { Dozór Kościelny, Rada Parafialna }\end{array}$ & \\
\hline 4 & $\begin{array}{l}\text { Die Wahl und Bestätigung der Kirchenvorsteher und Gemeinde-Repräsentanten in der } \\
\text { Parochie Loebau. (Poszyt, j. niem., k. 245; registr. W12) }\end{array}$ & $1844-1896$ \\
\hline 5 & Die Kirchenwahlen. (Poszyt, j. niem., pol., k. 107) & $1899-1934$ \\
\hline 6 & Kirchen-Gemeindevertretung. (Poszyt, j. niem., pol., k. 88) & $1876-1911$ \\
\hline 7 & $\begin{array}{l}\text { Protokollbuch der katholischen Kirchen-Gemeinde-Vertretung in Loebau. (Księga, } \\
\text { j. niem., pol., k. 119) }\end{array}$ & $1876-1928$ \\
\hline \multirow[t]{2}{*}{8} & $\begin{array}{l}\text { Protokollbuch des kathol. Kirchenvorstandes in Loebau. } \\
\text { (Księga, j. niem., pol., k. 95) }\end{array}$ & $1876-1933$ \\
\hline & III. Rozporządzenia władz kościelnych i państwowych & \\
\hline 9 & $\begin{array}{l}\text { Akta z czasów Księstwa Warszawskiego. Rozporządzenia władz państwowych. } \\
\text { (Poszyt, j. pol., niem., k. 24) }\end{array}$ & $1806-1809$ \\
\hline $9 a$ & $\begin{array}{l}\text { Akta z czasów Księstwa Warszawskiego. Rozporządzenia władz państwowych. } \\
\text { (Poszyt, j. pol., niem., k. 66) }\end{array}$ & $1807-1808$ \\
\hline 10 & $\begin{array}{l}\text { Currenden-Buch der katholischen Pfarrkirche zu Loebau. } \\
\text { (Poszyt, j. niem., k 73) }\end{array}$ & $1834-1854$ \\
\hline 11 & $\begin{array}{l}\text { Verschiedene Verordnungen betr. die Jahres-Rechnungen der Kirchen-Kasse Loebau. } \\
\text { (Poszyt, j. niem., pol., k. 29) }\end{array}$ & $1836-1852$ \\
\hline 12 & $\begin{array}{l}\text { Instruktion für die sämmtliche Pfarrer, Pfarr-Administratoren und Vorsteher von Kir- } \\
\text { chen und Stiftungen, die Verwaltung und Beaufsichtigung des katholischen Kirchen-, } \\
\text { Pfarr- und Stiftungs-Vermögens, sowie die Rechnungslegung darüber in der Diöcese } \\
\text { Culm } 1852 \text { betreffend vom 29. Oktober 1850, Culm 1852. (Druk, k. 36; powyższa } \\
\text { Instrukcja w jęz. pol. pod sygn. 11) }\end{array}$ & $1850-1852$ \\
\hline 13 & $\begin{array}{l}\text { Sammlung von Rescripten und Verfügungen in kirchlichen Angelegenheiten, die nicht } \\
\text { besonderen Akten gehören. } \\
\text { (Poszyt, j. niem., k. 73; registr. R5) }\end{array}$ & 1867-1895 \\
\hline 14 & Die polizeilichen Genehmigungen. (Poszyt, j. niem., k. 15) & $1895-1897$ \\
\hline
\end{tabular}




\begin{tabular}{|c|c|c|}
\hline Sygn. & Tytuł jednostki & Daty \\
\hline & IV. Kościół i budynki parafialne - inwentarze, inwestycje, remonty & \\
\hline 15 & Pfarr-Kirchen-Inventarium. (Poszyt, j. pol., niem., k. 63; registr. 11) & $1707-1890$ \\
\hline 16 & $\begin{array}{l}\text { Inventarium des der Verwaltung des katholischen Pfarr-Kirchenvorstandes zu Loebau } \\
\text { unterliegenden Vermögens. } \\
\text { (Księga, j. niem., s. 330; s 63-73 wykaz akt Archiwum Parafialnego) }\end{array}$ & 1889 \\
\hline 17 & Kirchenbauten Loebau. (Poszyt, j. niem., pol., k. 258; registr. K15) & $1823-1902$ \\
\hline 18 & $\begin{array}{l}\text { Die Besichtigung der kirchlichen Gebäude und der damit verbundenen Reparaturen } \\
\text { in Loebau. (Poszyt, j. niem., k. 117; registr. B10') }\end{array}$ & $1896-1905$ \\
\hline 19 & $\begin{array}{l}\text { Die Besichtigung der kirchlichen Gebäude und der damit verbundenen Reparaturen } \\
\text { in Loebau. (Poszyt, j. niem., k. 64; registr. B10") }\end{array}$ & $1905-1908$ \\
\hline 20 & Pfarrbauten. (Poszyt, j. niem., k. 258; registr. P6) & $1800-1899$ \\
\hline 21 & $\begin{array}{l}\text { Bauten. Besichtigung der Pfarrgebäude und Reparaturen. } \\
\text { (Poszyt, j. niem., k. 37; sygn. registr. B2) }\end{array}$ & $1907-1909$ \\
\hline 22 & Apartement am Vicarien-Hause. (Poszyt, j. niem., pol., k. 166; reigstr. A6) & $1857-1934$ \\
\hline 23 & $\begin{array}{l}\text { Reparatur des Viehs- und Pferde-Stalles auf dem Pfarrvorwerk. } \\
\text { (Poszyt, j. niem., k. 183; registr. R11) }\end{array}$ & $1847-1892$ \\
\hline 24 & $\begin{array}{l}\text { Feuer-Societäts-Beiträge für die Kirchen- und Pfarr-Gebäude. } \\
\text { (Poszyt, j. niem., k. 115; registr. F5) }\end{array}$ & $1844-1894$ \\
\hline 25 & Die Orgel der hiesigen Pfarrkirche. (Poszyt, j. niem., k. 72; registr. 015) & $1824-1890$ \\
\hline 26 & Neue Orgel und Reparaturen. (Poszyt, j. niem., pol., k. 70) & $1901-1917$ \\
\hline 27 & $\begin{array}{l}\text { Acta des Vorstandes der kath. Kirche zu Loebau in Sachen desselben wider den } \\
\text { Glockengiesser Friedrich Schulz zu Culm wegen Umgiessung mehrerer Glocken. } \\
\text { (Poszyt, j. niem., k. 142) }\end{array}$ & $1840-1849$ \\
\hline 28 & Blitzableiter auf der Pfarrkirche. Turmuhr. (Poszyt, j. niem., k.11; registr. B1) & $1901-1907$ \\
\hline 29 & $\begin{array}{l}\text { Baufonds von } 100 \text { Thalern zur Unterhaltung des Daches auf dem Pfarrhause. } \\
\text { (Poszyt, j. niem., k 19; registr. B5) }\end{array}$ & $1855-1914$ \\
\hline 30 & $\begin{array}{l}\text { Neuerrichtung eines Brunnen auf dem katholischen Kirchhofe in Loebau. Studnia na } \\
\text { cmentarzu. (Poszyt, j. pol., niem., k. 12; registr. B8) }\end{array}$ & 1896 \\
\hline $30 a$ & $\begin{array}{l}\text { Renowacja kościoła parafialnego i kaplicy M. B. Lipskiej. } \\
\text { (Teczka akt luźnych, j. pol., niem., k. 27) }\end{array}$ & $1891-1898$ \\
\hline 31 & „Zamek”. Dowody rachunków. (Poszyt, j. pol., k. 137) & 1929-1932 \\
\hline 32 & $\begin{array}{l}\text { Zniszczenia wojenne i ich naprawy. (Inwestycje dziesięciolecia 1946-1956). } \\
\text { (Skoroszyt, j. pol., k. 14) }\end{array}$ & $1945-1956$ \\
\hline 33 & Odnowienie fary. (Skoroszyt, j. pol., k. 21) & $1946-1957$ \\
\hline 34 & $\begin{array}{l}\text { Kościół św. Anny w Lubawie. Ołtarz główny i jego obrazy. Ołtarze boczne. Konser- } \\
\text { wacja. (Poszyt, j. pol., k. 85) }\end{array}$ & 1954-1956 \\
\hline 35 & Ołtarz Św. Rodziny. Konserwacja 1957. (Skoroszyt, j. pol., k. 7) & $1956-1957$ \\
\hline $35 a$ & $\begin{array}{l}\text { Feretrony. Obrazy. Obraz Serca Jezusowego. Drobniejsze zabytki. Konserwacja. } \\
\text { (Skoroszyt, j. pol., niem., k. 48) }\end{array}$ & $1953-1959$ \\
\hline
\end{tabular}




\begin{tabular}{|c|c|c|}
\hline Sygn. & Tytuł jednostki & Daty \\
\hline 36 & Ławki. (Skoroszyt, j. pol., rysunki i projekty wyk. techniką luksogr., k. 28) & $1955-1956$ \\
\hline 37 & $\begin{array}{l}\text { Centralne ogrzewanie w plebanii. Vol. } 1 . \\
\text { (Skoroszyt, j. pol., k. 32, rys. techn.) }\end{array}$ & $1955-1956$ \\
\hline 38 & $\begin{array}{l}\text { Centralne ogrzewanie w plebanii. Vol. 2: Dokumentacja techn. } \\
\text { (Skoroszyt, j. pol., k. 6) }\end{array}$ & $1955-1956$ \\
\hline & V. Kościoły i kaplice na terenie parafii & \\
\hline & a/ Sanktuarium Matki Boskiej Lipskiej w Lipach & \\
\hline 39 & $\begin{array}{l}\text { Regestra perceptorum ac expensarum Capellae Visitationis Beatae Virginis Mariae } \\
\text { ad Nemus.... (Księga opr. skórę, j. łac., pol., niem., k. 115) }\end{array}$ & $1741-1869$ \\
\hline 40 & $\begin{array}{l}\text { Documente und Werthpapiere der Kapelle Lip. } \\
\text { (Poszyt, j. niem., k. 10) }\end{array}$ & $1828-1876$ \\
\hline 41 & $\begin{array}{l}\text { Acta des Magistrats zu Loebau betr. das Vermögen der Kirche Lipp. } \\
\text { (Poszyt, j. niem., k. 145; registr. L22) }\end{array}$ & $1822-1886$ \\
\hline 42 & $\begin{array}{l}\text { Die Kapelle Lipp. Verschiedenes. (Akta gospodarczo-budowlane). } \\
\text { (Poszyt, j. niem., pol., k. 108; registr. K16) }\end{array}$ & $1847-1911$ \\
\hline 43 & $\begin{array}{l}\text { Akta tyczące odbudowy dnia } 12 \text { lipca } 1861 \text { spalonego kościoła w Lipach. } \\
\text { (Poszyt, j. niem., pol., k. 198) }\end{array}$ & $1861-1894$ \\
\hline 44 & $\begin{array}{l}\text { Rechnung über die Verwaltung der freiwilligen Beiträgen zum Wiederaufbau der im } \\
\text { Jahre } 1861 \text { abgebrannten Marienkapelle zu Lip. } \\
\text { (Teczka, } 6 \text { składek, j. niem., k. 12) }\end{array}$ & $1861-1867$ \\
\hline 45 & $\begin{array}{l}\text { Neubau eines Unterkunfts-Häuschens in Lipy. } \\
\text { (Poszyt, j. niem., k. 10; sygn. registr. L7) }\end{array}$ & $1900-1901$ \\
\hline 46 & $\begin{array}{l}\text { Einnahme-Journal der Kapelle Lip bei Loebau. Ausgabe-Journal der Kapelle Lip bei } \\
\text { Loebau. (Księga, j. niem., k. 106) }\end{array}$ & $1876-1912$ \\
\hline 47 & $\begin{array}{l}\text { Acta der Marien-Kapelle zu Lip das Rechnungswesen derselben betreffend. } \\
\text { (Poszyt, j. niem., k. 242; registr. R12) }\end{array}$ & $1852-1897$ \\
\hline 48 & $\begin{array}{l}\text { Rechnung über die Vermögens-Verwaltung der katholischen Kirchen-Kapelle zu Lip } \\
\text { bei Loebau. (Składki } 7 \text {, j. niem., k. 48) }\end{array}$ & $1853-1859$ \\
\hline 49 & $\begin{array}{l}\text { Rechnung über die Vermögens-Verwaltung der katholischen Kirchen-Kapelle zu Lip } \\
\text { bei Loebau. (Łącznie z inwentarzami). } \\
\text { (Teczka, } 15 \text { składek, j. niem., k 181) }\end{array}$ & $1860-1874$ \\
\hline 50 & $\begin{array}{l}\text { Rechnung über die Vermögens-Verwaltung der katholischen Marien-Kapelle zu Lip. } \\
\text { (Łącznie z inwentarzami). } \\
\text { (Teczka, } 16 \text { składek, j. niem., k 195) }\end{array}$ & 1875-1895 \\
\hline 51 & $\begin{array}{l}\text { Beläge zur Rechnung über die Vermögensverwaltung der Marien-Kapelle in Lipy bei } \\
\text { Loebau. (Poszyty 9, j. niem., k. 278) }\end{array}$ & 1890-1916 \\
\hline 52 & $\begin{array}{l}\text { Rechnung über die Verwaltung der bei der katholischen Kapelle Lipp bei Leobau... } \\
\text { vorhandenen Stiftungs-Vermögens. } \\
\text { (Teczka, } 18 \text { składek, j. niem., k. } 65 \text { ) }\end{array}$ & 1874-1895 \\
\hline 53 & $\begin{array}{l}\text { Beläge zur Rechnung über das Nicolaus Rochon'sche Stiftung bei der Kirche Lip bei } \\
\text { Loebau pro 1874. (Poszyt, j. niem., k. 7) }\end{array}$ & 1874 \\
\hline
\end{tabular}




\begin{tabular}{|c|c|c|}
\hline Sygn. & Tytuł jednostki & Daty \\
\hline 54 & $\begin{array}{l}\text { Acta der Pfarrkirche zu Loebau betr. } 60 \text { Thal. } 20 \text { Sgr, auf dem Grundstück Loebau } \\
\text { No } 89 \text { ausstehendes Kapital der Marienkapelle zu Lip. } \\
\text { (Poszyt, j. niem., k. 82) }\end{array}$ & $1828-1873$ \\
\hline 55 & $\begin{array}{l}\text { Acta der Kapelle Lip betr. die ehemals dem S. Georg-Hospital gehörigen, auf dem } \\
\text { Grundstück Loebau № } 321 \text {, Rubr. III № } 1 \text { eingetragenen } 200 \text { Thal. } \\
\text { (Poszyt, j. niem., k. 44) }\end{array}$ & $1868-1872$ \\
\hline 56 & $\begin{array}{l}\text { Sanktuarium Matki Boskiej Lipskiej w Lipach - programy uroczystości odpustowych } \\
\text { w Lipach, informacje. } \\
\text { (Teczka akt luźnych, j. pol., k. 40) }\end{array}$ & 1894-1994 \\
\hline \multirow[t]{2}{*}{57} & $\begin{array}{l}\text { Projekty przebudowy kościoła w Lipach. Plany sytuacyjne. } \\
\text { (Teczka, } 6 \text { rys. techn.) }\end{array}$ & $1945-1951$ \\
\hline & b/ Kościół św. Barbary w Lubawie (zob. szpital św. Jerzego) & \\
\hline 58 & $\begin{array}{l}\text { Kościół św. Barbary w Lubawie. Dane historyczne dotyczące kościoła św. Barbary } \\
\text { tłumaczone z kroniki niemieckiej z r. } 1892 . \\
\text { (Skoroszyt, maszynop., j. pol., k. 11, k. } 2 \text { wydarta) }\end{array}$ & 1892 \\
\hline 59 & $\begin{array}{l}\text { Budowa nowych organów w kościele św. Barbary w Lubawie. } \\
\text { (Poszyt, j. pol., niem., k. 28) }\end{array}$ & 1909 \\
\hline \multirow[t]{2}{*}{60} & $\begin{array}{l}\text { Budowa organów w kościele św. Barbary w Lubawie. } \\
\text { (Poszyt, j. niem., k. 16) }\end{array}$ & 1910 \\
\hline & c/ Kaplica Wniebowstąpienia Pańskiego w Mortęgach & \\
\hline \multirow[t]{2}{*}{61} & Kaplica w Mortęgach. (Skoroszyt, j. pol., k. 17) & $1952-1957$ \\
\hline & VI. Duszpasterstwo. Służba Boża. Sakramenty św. & \\
\hline 62 & $\begin{array}{l}\text { Kinderannahme zur ersten hl. Kommunion. } \\
\text { (Poszyt, j. niem., pol., k. 126; registr. K18) }\end{array}$ & $1818-1898$ \\
\hline 63 & Fronleichnams-Prozession. (Poszyt, j. niem., k. 76) & $1890-1901$ \\
\hline 64 & Die hl. Mission in Loebau. (Poszyt, j. niem., pol., k. 64) & $1898-1924$ \\
\hline 65 & $\begin{array}{l}\text { Facultas benedicendi crucem et statuas sanctorum. } \\
\text { (Poszyt, j. niem., k. 60) }\end{array}$ & $1897-1909$ \\
\hline 66 & $\begin{array}{l}\text { Verschiedene Verordnungen betr. Ehesachen-Trauungen von Militärpflichtigen Aus- } \\
\text { ländern. (Poszyt i luzy, j. niem., pol., k. 34) }\end{array}$ & $1815-1885$ \\
\hline 67 & Die gemieschten Ehen. (Poszyt, j. niem., pol., k. 87; registr. E1) & $1875-1914$ \\
\hline 68 & Eheseparations-Sachen. (Poszyt, j. niem., pol., k. 44; registr. E5) & $1851-1908$ \\
\hline 69 & Publicanda 1926-1929. (Zeszyt opr., j. pol., k. 183) & $1926-1929$ \\
\hline 70 & Publicanda 1932-1935. (Zeszyt opr., j. pol., k. 164) & $1932-1935$ \\
\hline 71 & Publicanda 1935-1937. (Zeszyt opr., j. pol., k. 109) & $1935-1937$ \\
\hline 72 & $\begin{array}{l}\text { Proclamationes - Zapowiedzi przedślubne 1910-1920. Wymianki za zmarłych } \\
\text { fundacyjne i roczne 1910-1921. } \\
\text { (Zeszyt opr., j. pol., k.123) }\end{array}$ & $1910-1921$ \\
\hline 73 & $\begin{array}{l}\text { Zapowiedzi przedślubne (Proclamationes). } \\
\text { (Zeszyt opr., j. pol., k. 76) }\end{array}$ & $1930-1935$ \\
\hline 74 & Zapowiedzi przedślubne. (Zeszyt opr., j. pol., k. 92) & $1975-1984$ \\
\hline 75 & $\begin{array}{l}\text { Wielka Nowenna. Materiały Instytutu Prymasowskiego Ślubów Narodu. (Teczka, } \\
\text { maszynopisy, j. pol., k. 145) }\end{array}$ & 1960 \\
\hline
\end{tabular}




\begin{tabular}{|c|c|c|}
\hline Sygn. & Tytuł jednostki & Daty \\
\hline 76 & $\begin{array}{l}\text { Listy pasterskie ks. biskupa Kazimierza Józefa Kowalskiego i ks. prymasa Stefana } \\
\text { Wyszyńskiego dotyczacce W. Nowenny i II Soboru Watykańskiego. (Teczka, maszy- } \\
\text { nopisy, j. pol., k. 321) }\end{array}$ & 1962 \\
\hline 77 & $\begin{array}{l}\text { Rok Maryjny 1965. Akt oddania w macierzyńską niewolę. Materiały duszpasterskie. } \\
\text { (Teczka, maszynopisy, j. pol.) }\end{array}$ & 1965 \\
\hline 78 & $\begin{array}{l}\text { Księga Wieczysta. Votum parafii Lubawa. Zobowiązania Tysiąclecia 1965-1966. } \\
\text { (Księga, j. pol., k. 180) }\end{array}$ & $1965-1966$ \\
\hline \multirow[t]{3}{*}{79} & $\begin{array}{l}\text { Piesza Pielgrzymka Pomorska z Lubawy na Jasną Górę. Grupa „Ziemia Lubawska”. } \\
\text { Trasa i regulamin. (Druk, j. pol., k. 14) }\end{array}$ & b.r. \\
\hline & VII. Bractwa i stowarzyszenia kościelne & \\
\hline & a/ Bractwo Różańca Świętego & \\
\hline 80 & $\begin{array}{l}\text { Album (Archi) Confraternitatis Sacratissimi Rosarii Beatae Virginis Mariae in Ecclesia } \\
\text { Archi-Presbyterali Lubaviensi 1768-1937. Acta Confraternitatis Sacratissimi Rosarii } \\
\text { Beatae Virginis Mariae in Ecclesia Archi-Persbyterali Lubaviensi 1852-1907. } \\
\text { (Księga, j. tac., pol., k. 252) }\end{array}$ & $1768-1937$ \\
\hline 81 & $\begin{array}{l}\text { Sodalitas Sacratissimi Rosarii. Indulgentiae per Summos Pontifices sodalibus SS. } \\
\text { Rosarii caeterisque christifidelibus concessae. } \\
\text { (Karta } 55,5 \times 76 \mathrm{~cm} \text {, j. tac.) }\end{array}$ & ok. 1930 \\
\hline 82 & $\begin{array}{l}\text { Einnahme-Journal der Rosenkranz-Bruderschaft zu Loebau. Ausgabe-Journal der } \\
\text { Rosenkranz-Bruderschaft zu Loebau. } \\
\text { (Księga, j. niem., k. 119) }\end{array}$ & $1876-1910$ \\
\hline 83 & $\begin{array}{l}\text { Rechnung über die Vermögens-Verwaltung der bei der kathol. Pfarr-Kirche der } \\
\text { hl. Anna zu Loebau vorhandenen Bruderschaft des hl. Rosenkranzes. } \\
\text { (Teczka, } 11 \text { składek, j. niem., k. 100) }\end{array}$ & $1853-1863$ \\
\hline 84 & $\begin{array}{l}\text { Rechnung über die Vermögens-Verwaltung der bei der kathol. Pfarr-Kirche der } \\
\text { hl. Anna zu Loebau vorhandenen Bruderschaft des hl. Rosenkranzes. } \\
\text { (Teczka, } 15 \text { składek, j. niem., k. 142) }\end{array}$ & $1865-1879$ \\
\hline 85 & $\begin{array}{l}\text { Rechnung über die Vermögens-Verwaltung der bei der kathol. Pfarr-Kirche der } \\
\text { hl. Anna zu Loebau vorhandenen Rosenkranz-Bruderschaft. } \\
\text { (Teczka, } 19 \text { składek, j. niem., k. 175) }\end{array}$ & $1880-1903$ \\
\hline 86 & $\begin{array}{l}\text { Beläge zu der Rechnung über die Vermögens-Verwaltung bei der katholischen Pfarr- } \\
\text { Kirche zu Loebau vorhandenen Rosenkranz-Bruderschaft. } \\
\text { (Teczka, } 2 \text { poszyty, j. niem., k. 90) }\end{array}$ & $1909-1915$ \\
\hline 87 & $\begin{array}{l}\text { Acta betr. die zur hiesigen Rosenkranz-Bruderschaft gehörigen Johann Fabri- } \\
\text { cius'schen Stiftungen. } \\
\text { (Poszyt, j. niem., łac., k. 12; registr. F3) }\end{array}$ & $1890-1891$ \\
\hline 88 & $\begin{array}{l}\text { Rosenkranz-Bruderschaft Prątnicki'sche Stiftung, Fabricius'-Stiftung. (Sparkassen- } \\
\text { buch der Sparkasse des Kreises Löbau). } \\
\text { (Książeczka bankowa, j. niem., k. 23) }\end{array}$ & $1902-1934$ \\
\hline & b/ Bractwo Aniołów Stróżów & \\
\hline 89 & $\begin{array}{l}\text { Cathalogus Confraternitatis SS. Angelorum Custodum comparatus Anno Domini } \\
\text { MDCCXCVIII cura A. R. Ignatii Sienicki Vic[arii] Lubav[iensis]. } \\
\text { (Księga, j. tac., pol., niem., k 172) }\end{array}$ & $1798-1945$ \\
\hline 90 & Die Bruderschaft der h. Schutzengel. (Poszyt, j. niem., k. 27) & $1852-1894$ \\
\hline 91 & $\begin{array}{l}\text { Rechnung über die Vermögens-Verwaltung der bei der kathol. Pfarr-Kirche der } \\
\text { hl. Anna zu Loebau vorhandenen Schutzengel-Bruderschaft. } \\
\text { (Teczka, } 41 \text { składek, j. niem., k 188) }\end{array}$ & $1853-1901$ \\
\hline
\end{tabular}




\begin{tabular}{|c|c|c|}
\hline Sygn. & Tytuł jednostki & Daty \\
\hline \multirow[t]{2}{*}{92} & $\begin{array}{l}\text { Schutzengel-Bruderschaft Rechnungen. (Rechnung über die Vermögens-Verwaltung } \\
\text { der bei der katholischen Pfarr-Kirche zu Loebau vorhandenen Schutzengel-Bruder- } \\
\text { schaft. } \\
\text { (Poszyt, j. niem., k. 50) }\end{array}$ & $1902-1916$ \\
\hline & c/ Inne stowarzyszenia kościelne & \\
\hline 93 & $\begin{array}{l}\text { Księga zawierająca w sobie imiona braci i sióstr Archikonfraterni Bożego Cia- } \\
\text { ła z opisaniem odpustów i sposobów dostąpienia tychże. (Księga, j. tac., pol., } \\
\text { s. 380, zapis. 180) }\end{array}$ & $1759-1936$ \\
\hline 94 & $\begin{array}{l}\text { 1. Confraternitas Immaculatae Conceptionis Beatissimae Virginis Mariae Deiparae } \\
\text { (1682-1726); 2. Confraternitas s. Annae (1672-1708) - ad Ecclesiam (Aedes) } \\
\text { SS. Michaelis Archangeli et s. Ioannis Baptistae Conventus Lubaviensis PP. Bernar- } \\
\text { dinorum. (Poszyt, j. tac., pol., k. 24) }\end{array}$ & $1672-1726$ \\
\hline 95 & $\begin{array}{l}\text { Das Werk zur Verbreitung des Glaubens zum Besten der Missionen beider Welten } \\
\text { (Franciscus-Xaverius-Verein). (Poszyt, j. niem., pol., k. 20) }\end{array}$ & $1844-1872$ \\
\hline 96 & $\begin{array}{l}\text { Bonifacius-Adalbertus-Verein in der Diözese Culm. (Teczka, luźne kartki i druki, } \\
\text { j. niem., pol., k. 28; registr. B3) }\end{array}$ & $1859-1873$ \\
\hline 97 & $\begin{array}{l}\text { Enthaltsamkeits- und Mässigkeits-Verein (Bractwo Trzeźwości). } \\
\text { (Poszyt, j. łac., pol., niem., k. 55) }\end{array}$ & $1848-1899$ \\
\hline 98 & $\begin{array}{l}\text { Towarzystwa w parafii: Towarzystwo Ludowe - Liga Katolicka, Dzieci Maryi, Towarzy- } \\
\text { stwo Katolickiej Młodzieży - Stowarzyszenie Młodzieży Męskiej i Żeńskiej, Katolickie } \\
\text { Stowarzyszenie Czeladzi. (Poszyt, j. łac., pol., niem., k. 121) }\end{array}$ & $1893-1935$ \\
\hline 99 & $\begin{array}{l}\text { Sprawy misyjne. Papieskie Dzieło Rozkrzewiania Wiary. Diecezjalne Dzieło Rozkrze- } \\
\text { wiania Wiary. (Poszyt, luzy, j. pol., niem., k. 52) }\end{array}$ & $1934-1939$ \\
\hline 100 & $\begin{array}{l}\text { Stowarzyszenie Pań Miłosierdzia św. Wincentego à Paulo. Sprawy charytatywne. } \\
\text { (Skoroszyt i luzy, j. pol., k. 103) }\end{array}$ & $1937-1939$ \\
\hline 101 & Okólniki Akcji Katolickiej. (Maszynop. powiel., j. pol., k. 39) & 1938-1939 \\
\hline 102 & Apostolstwo Modlitwy (dyplomy). (Teczka, druki, j. pol., k. 29) & 1947 \\
\hline 103 & $\begin{array}{l}\text { Bractwo Straży Honorowej Najśw. Serca Pana Jezusa. } \\
\text { (Teczka, } 2 \text { księgi, koresp., dekrety, dyplomy) }\end{array}$ & 1949 \\
\hline 104 & Krucjata Eucharystyczna. (Teczka, druki, kwity, j. pol., k. 133) & $1947-1950$ \\
\hline \multirow[t]{3}{*}{105} & Stowarzyszenie Dzieciątka Jezus. (Teczka, j. pol., k. 30) & $1947-1948$ \\
\hline & VIII. Statystyka ludnościowa & \\
\hline & a/ Statystyka parafialna, zmiany granic parafii & \\
\hline 106 & Bevölkerungslisten für die Parochie Loebau. (Poszyt, j. niem., k. 106; registr. B4) & $1810-1892$ \\
\hline 107 & Verzeichniss der Parochianen. (Poszyt, j. niem., k. 310) & $1839-1860$ \\
\hline 108 & Berichtigungen in den Kirchen-Büchern. (Poszyt, j. niem., k.74; registr. K11) & $1880-1909$ \\
\hline 109 & $\begin{array}{l}\text { Die Katholiken in Ostpreussen. (Okolice Lubawy: Lubstynek, Glaznoty, Wygoda, Klin, } \\
\text { Dylewo, Zajączki, Lipow0, Bałcyny, Dąbrówno ii.). } \\
\text { (Poszyt, j. niem., pol., k 18; registr. A1) }\end{array}$ & $1859-1860$ \\
\hline 110 & $\begin{array}{l}\text { Die Umpfarrung (Targowisko, Lubstynek, Złotowo). } \\
\text { (Poszyt, j. niem., k. 17; registr. U4) }\end{array}$ & $1901-1923$ \\
\hline
\end{tabular}




\begin{tabular}{|c|c|c|}
\hline Sygn. & Tytuł jednostki & Daty \\
\hline & b/ Księgi USC z okresu Księstwa Warszawskiego & \\
\hline 111 & $\begin{array}{l}\text { Księga urodzonych gminy lubawskiej w pow. michałowskim od } 1 \text { maja } 1813 \text { do } \\
\text { końca kwietnia } 1814 \text {. } \\
\text { (Księga b. uszkodz., j. pol., k 32) }\end{array}$ & $1813-1814$ \\
\hline 112 & $\begin{array}{l}\text { Akta zapowiedzi (przedślubnych) gminy lubawskiej w powiecie michałowskim, } \\
\text { departamencie bydgoskim od } 1 \text { maja } 1808 \text { do ostatniego kwietnia } 1809 . \\
\text { (Księga, j. pol., k. 12) }\end{array}$ & $1808-1809$ \\
\hline 113 & $\begin{array}{l}\text { Akta zapowiedzi gminy lubawskiej (...) od } 1 \text { maja } 1809 \text { do ostatniego kwietnia } \\
\text { 1810. (Księga, j. pol., k. 11) }\end{array}$ & $1809-1810$ \\
\hline 114 & $\begin{array}{l}\text { Akta zapowiedzi gminy lubawskiej (...) od } 1 \text { maja } 1810 \text { do } 1 \text { maja } 1811 . \\
\text { (Księga, j. pol., k. 15) }\end{array}$ & $1810-1811$ \\
\hline 115 & $\begin{array}{l}\text { Akta zapowiedzi gminy lubawskiej (...) od } 12 \text { maja } 1811 \text { do } 26 \text { stycznia } 1812 . \\
\text { (Księga, j. pol., k. 11) }\end{array}$ & $1811-1812$ \\
\hline 116 & $\begin{array}{l}\text { Akta małżeństwa gminy lubawskiej w pow. michałowskim, departamencie bydgoskim } \\
\text { od } 1 \text { maja } 1808 \text { do ostatniego kwietnia 1809. (Ksiegaa, j. pol., k. 18) }\end{array}$ & $1808-1809$ \\
\hline 117 & $\begin{array}{l}\text { Akta małżeństwa gminy lubawskiej (...) od } 1 \text { maja } 1809 \text { do ostatniego kwietnia } \\
\text { 1810. (Księga, j. pol., k. 21) }\end{array}$ & $1809-1810$ \\
\hline 118 & $\begin{array}{l}\text { Akta małżeństwa gminy lubawskiej (...) od dnia } 1 \text { maja } 1810 \text { do ostatniego kwietnia } \\
\text { 1811. (Księga, j. pol., k. 20) }\end{array}$ & $1810-1811$ \\
\hline 119 & $\begin{array}{l}\text { Akta małżeństwa gminy lubawskiej (...) od } 1 \text { maja } 1811 \text { do ostatniego kwietnia } \\
\text { 1812. (Księga, j. pol., k. 16) }\end{array}$ & $1811-1812$ \\
\hline 120 & $\begin{array}{l}\text { Akta zejścia gminy lubawskiej w powiecie michałowskim, departamencie bydgoskim } \\
\text { od } 1 \text { maja } 1808 \text { do } 1 \text { maja } 1809 . \\
\text { (Księga, j. pol., k. 35) }\end{array}$ & $1808-1809$ \\
\hline 121 & $\begin{array}{l}\text { Akta zejścia gminy lubawskiej (...) od } 1 \text { maja } 1809 \text { do ostatniego kwietnia } 1810 . \\
\text { (Księga, j. pol., k. 47) }\end{array}$ & $1809-1810$ \\
\hline 122 & $\begin{array}{l}\text { Akta zejścia gminy lubawskiej 9...) od } 1 \text { maja } 1810 \text { do } 1 \text { maja } 1811 . \\
\text { (Księga, j. pol., k. 22) }\end{array}$ & $1810-1811$ \\
\hline \multirow[t]{2}{*}{123} & $\begin{array}{l}\text { Akta zejścia gminy lubawskiej (...) od } 1 \text { maja } 1811 \text { do ostatniego kwietnia } 1812 . \\
\text { (Księga, j. pol., k. 21) }\end{array}$ & $1811-1812$ \\
\hline & IX. Stosunki wyznaniowe & \\
\hline 124 & $\begin{array}{l}\text { Die seit dem Jahre } 1846 \text { vorgekommenen Conversionen. } \\
\text { (Poszyt, j. niem., tac., k. 145; registr. C4) }\end{array}$ & $1846-1908$ \\
\hline 125 & Akten betr. die hiesigen Altkatholiken. (Poszyt, j. niem., k. 81) & $1869-1882$ \\
\hline \multirow[t]{2}{*}{126} & $\begin{array}{l}\text { Die Heranziehung der Mitglieder der jüdischen Synagogen-Gemeinde zur Zahlung von } \\
\text { Pfarrbaubeitragen. (Poszyt, j. niem., k. 3; registr. S6) }\end{array}$ & $1870-1874$ \\
\hline & X. Szkolnictwo & \\
\hline 127 & Die Verordnungen betr. das Schulwesen. (Poszyt, j. niem., k. 327; registr. S11) & $1839-1882$ \\
\hline 128 & $\begin{array}{l}\text { Die Auflösung der Simultanschule und die Einrichtung der Confessionsschule. } \\
\text { (Poszyt, j. niem., k. 153; registr. A3) }\end{array}$ & $1827-1892$ \\
\hline
\end{tabular}




\begin{tabular}{|c|c|c|}
\hline Sygn. & Tytuł jednostki & Daty \\
\hline 129 & Die hiesige Simultan-Stadtschule. (Poszyt, j. niem., k. 211; registr. S10) & $1839-1903$ \\
\hline 130 & $\begin{array}{l}\text { Acta der Pfarrkirche resp. Katholische Schule Löbau betr. das der letzteren gehörige } \\
\text { Kapital von ein Tausend Thalern aus der Domherr Prątnicki'schen Stiftung. } \\
\text { (Poszyt, j. tac., pol., niem., k. 41; registr. P1, por. sygn. 204) }\end{array}$ & $1825-1854$ \\
\hline 131 & $\begin{array}{l}\text { Acta der Kreisschul-Inspections zu Loebau betr. die Schulamts-Präparande-Stelle zu } \\
\text { Loebau. (Poszyt, j. niem., k. 60; registr. S8) }\end{array}$ & $1864-1878$ \\
\hline 132 & $\begin{array}{l}\text { Nachrichten über das Elementar-Schulwesen in der Pfarrei Löbau. } \\
\text { (Poszyt, j. niem., k. 12) }\end{array}$ & 1895 \\
\hline 133 & $\begin{array}{l}\text { Początki szkoły wydziałowej i sprawy szkolne w ogóle. } \\
\text { (Poszyt, j. pol., niem., k. 122) }\end{array}$ & $1901-1937$ \\
\hline 134 & $\begin{array}{l}\text { Acta betr. die Leitung der Lehrer-Conferenzen des II. Bezirks. } \\
\text { (Poszyt, j. niem., k. 27) }\end{array}$ & $1870-1880$ \\
\hline 135 & $\begin{array}{l}\text { Verhandlungen über die Lehrer-Conferenzen aus dem Schulinspektions-Bezirke } \\
\text { Loebau I pro 1867. (Poszyt, j. niem., k. 10) }\end{array}$ & 1867 \\
\hline 136 & $\begin{array}{l}\text { Verhandlungen über die im Jahre } 1868 \text { im Conferenz-Bezirk Loebau abgehaltenen } \\
\text { Lehrer-Conferenzen. (Posz., j. niem., k. 7) }\end{array}$ & 1868 \\
\hline 137 & $\begin{array}{l}\text { Verhandlungen über die im Jahre } 1870 \text { im Conferenz-Bezirk Loebau abgehaltenen } \\
\text { Lehrer-Conferenzen. (Posz., j. niem., k. } 28 \text { ) }\end{array}$ & 1870 \\
\hline 138 & $\begin{array}{l}\text { Verhandlungen über die im Jahre } 1871 \text { im Conferenz-Bezirk Loebau abgehaltenen } \\
\text { Lehrer-Conferenzen. (Posz., j. niem, k. 23) }\end{array}$ & 1871 \\
\hline 139 & Lehrer-Conferenz-Arbeiten vom Jahre 1860 ab. (Poszyt, j. niem., k. 69) & $1859-1865$ \\
\hline 140 & $\begin{array}{l}\text { Conferenz-Arbeiten der Lehrer aus dem Loebauer Conferenz-Bezirk pro } 1866 . \\
\text { (Poszyt, j. niem., k. 51) }\end{array}$ & 1866 \\
\hline 141 & $\begin{array}{l}\text { Conferenz-Arbeiten aus dem Schulinspections-Bezirk Loebau I pro } 1867 . \\
\text { (Poszyt, j. niem., k. 94) }\end{array}$ & 1867 \\
\hline 142 & $\begin{array}{l}\text { Conferenz-Arbeiten aus dem Loebauer Conferenz-Bezirk pro } 1871 . \\
\text { (Poszyt, j. niem., k. 20) }\end{array}$ & 1871 \\
\hline 143 & Conferenz-Arbeiten aus dem Loebauer Conferenz-Bezirk. (Poszyt, j. niem., k. 17) & 1872 \\
\hline 144 & Akta dotyczące Szkoły Podoficerskiej w Lubawie. (Poszyt, j. pol., k. 15) & $1938-1939$ \\
\hline \multirow[t]{3}{*}{$144 a$} & Unterstützung hilfsbedürftiger Gymnasialisten. (Poszyt, j. niem., pol., k. 47) & $1839-1852$ \\
\hline & XI. Szpitale - domy ubogich & \\
\hline & a / Szpital św. Walentego & \\
\hline 145 & Akta szpitala św. Walentego. (Poszyt, j. niem., k. 22) & $1802-1806$ \\
\hline 146 & St. Valentin-Hospital. (Poszyt, j. niem., pol., k. 305; registr. V7') & $1822-1903$ \\
\hline 147 & S. Valentin-Armen-Hospital. (Poszyt, j. niem., k. 178; registr. V7") & $1826-1896$ \\
\hline 148 & $\begin{array}{l}\text { Reiestra percepty i expensy Xenodochy świętego Walentego, to iest ubogiego domu. } \\
\text { (Księga, j. pol., niem., k. 218) }\end{array}$ & $1775-1877$ \\
\hline 149 & Einnahme St. Valentin-Hospitals zu Loebau. (Księga, j. niem., k. 104) & 1876-1912 \\
\hline
\end{tabular}




\begin{tabular}{|c|c|c|}
\hline Sygn. & Tytuł jednostki & Daty \\
\hline 150 & $\begin{array}{l}\text { Jahres-Rechnung über die Verwaltung des Vermögens der St. Valentin Hospitals- } \\
\text {-Stiftung zu Loebau. (Teczka, } 16 \text { skł., j. niem., k. 109) }\end{array}$ & $1848-1863$ \\
\hline 151 & $\begin{array}{l}\text { Rechnung über die Vermögens-Verwaltung der katholischen Pfarrkirche zu Loebau } \\
\text { vorhandenen St. Valentin-Armen-Hospital-Stiftung zu Loebau. } \\
\text { (Teczka, } 13 \text { skl., j. niem., k. 209) }\end{array}$ & $1864-1875$ \\
\hline 152 & $\begin{array}{l}\text { Rechnung über die Vermögens-Verwaltung der kath. Pfarrkiche d. h. Anna zu Loebau } \\
\text { vorhandenen St. Valentin-Armen-Hospital-Stiftung zu Loebau. } \\
\text { (Teczka, } 15 \text { składek, j. niem., k. 149) }\end{array}$ & $1876-1894$ \\
\hline 153 & $\begin{array}{l}\text { Rechnung über die Vermögens-Verwaltung der kath. Pfarrkirche d. h. Anna zu Loebau } \\
\text { vorhandenen St. Valentin-Armen-Hospital zu Loebau. } \\
\text { (Poszyt, j. niem., pol., k. 291) }\end{array}$ & $1900-1927$ \\
\hline 154 & $\begin{array}{l}\text { Beläge zur Nachweisung über die Vermögens-Verwaltung des St. Valentin-Armen- } \\
\text {-Hospitals zu Loebau. (Teczka, } 3 \text { składki, j. niem., k. 83) }\end{array}$ & $1877-1879$ \\
\hline 155 & $\begin{array}{l}\text { Beläge und Quittungen zur Rechnung über die Vermögens-Verwaltung des kathol. } \\
\text { St. Valentin-Armen-Hospitals. (Teczka, } 2 \text { składki, j. niem., k. 33) }\end{array}$ & 1904-1916 \\
\hline 156 & $\begin{array}{l}\text { Dowody do rachunków szpitala św. Walentego w Lubawie. } \\
\text { (Teczka, składki 2, j. pol., k. 14) }\end{array}$ & $1937-1938$ \\
\hline 157 & $\begin{array}{l}\text { Stiftungsurkunden dem St. Valentin-Hospital zu Loebau gehörige. } \\
\text { (Poszyt, j. niem., k. 20) }\end{array}$ & $1836-1867$ \\
\hline 158 & $\begin{array}{l}\text { Vincenz v. Wodziński'sche Stiftung für die Pfleglinge des St. Valentin-Hospitals. } \\
\text { (Poszyt, j. niem., k. 15; registr. V3) }\end{array}$ & $1882-1884$ \\
\hline 159 & St. Valentin-Hospital. (Kauli'scher Kanon). (Poszyt, j. niem., k. 13; registr. V13) & 1903-1905 \\
\hline 160 & Neubau des S. Valentin-Hospitals. (Poszyt, j. niem., k. 56; registr. V10) & $1899-1902$ \\
\hline \multirow[t]{2}{*}{161} & $\begin{array}{l}\text { Szpital św. Walentego. (Urządzenie salki parafialnej. Projekt). } \\
\text { (Poszyt, j. pol., k. 39) }\end{array}$ & $1922-1939$ \\
\hline & $\begin{array}{l}\text { b/ Szpital św. Jerzego i kościół św. Barbary } \\
\text { (zob. kościół św. Barbary, sygn. 58-60) }\end{array}$ & \\
\hline 162 & $\begin{array}{l}\text { Etat für das St. Georgen-Hospital und die damit verbundene St. Barbara-Kirche zu } \\
\text { Loebau. (Poszyt, j. niem., k. 56) }\end{array}$ & $1847-1852$ \\
\hline 163 & $\begin{array}{l}\text { Rechnungs-Legung der Oberin der Barmherzigen Schwestern. } \\
\text { (Poszyt, j. pol., k. 22) }\end{array}$ & $1862-1866$ \\
\hline 164 & $\begin{array}{l}\text { Einnahme-Journal des St. Georgen-Hospitals zu Loebau. Ausgabe-Journal des } \\
\text { St. Georgen-Hospitals zu Loebau. (Poszyt., j. niem., k. 154) }\end{array}$ & $1876-1910$ \\
\hline 165 & $\begin{array}{l}\text { Kirchen-Rechnung der St. Barbara-Kirche und des St. Georgen-Hospitals zu Loebau. } \\
\text { (Teczka, składki 4, j. pol., niem., k. 42) }\end{array}$ & $1796-1818$ \\
\hline 166 & $\begin{array}{l}\text { Rechnung von der Kasse des St. Georgen-Hospitals zu Leobau. } \\
\text { (Teczka, składki 2, j. niem., k. 44) }\end{array}$ & $1852-1853$ \\
\hline 167 & $\begin{array}{l}\text { Rechnung über die Vermögens-Verwaltung des St. Georgen-Hospitals und der damit } \\
\text { verbundenen St. Barbara-Kirche zu Loebau. (Teczka, składki 4, j. niem., k. 76) }\end{array}$ & $1856-1859$ \\
\hline 168 & $\begin{array}{l}\text { Rechnung über die Vermögens-Verwaltung der katholischen St. Georgen-Hospitals- } \\
\text {-Stiftung und der damit verbundenen St. Barbara-Kirche zu Loebau. } \\
\text { (Teczka, składki 13, j. niem., k. 272) }\end{array}$ & 1863-1889 \\
\hline
\end{tabular}




\begin{tabular}{|c|c|c|}
\hline Sygn. & Tytuł jednostki & Daty \\
\hline 169 & $\begin{array}{l}\text { Rechnung über die Vermögens-Verwaltung der katholischen St. Georgen-Armen- } \\
\text {-Hospitals-Stiftung und der damit verbundenen Kirche der hl. Barbara zu Loebau. } \\
\text { (Teczka, skł. 8, j. niem., k. 127) }\end{array}$ & $1890-1903$ \\
\hline 170 & $\begin{array}{l}\text { Rechnung über die Verwaltung des bei dem St. Georgen-Hospital und der damit } \\
\text { verbundenen St. Barbara-Kirche zu Loebau vorhandenen Stiftungs-Vermögens. } \\
\text { (Teczka, składki 14, j. niem., k. 60) }\end{array}$ & $1880-1896$ \\
\hline 171 & $\begin{array}{l}\text { Beläge zur Rechnung über die Vermögens-Verwaltung der kath. St. Georgen-Hospitals } \\
\text { zu Loebau. (Teczka, skł. 4, j. niem., k. 79) }\end{array}$ & $1903-1917$ \\
\hline 172 & $\begin{array}{l}\text { Dowody do rachunków szpitala św. Jerzego w Lubawie. } \\
\text { (Poszyt, j. pol., k. 35) }\end{array}$ & 1929 \\
\hline 173 & $\begin{array}{l}\text { Dowody do rachunków szpitala św. Jerzego w Lubawie. } \\
\text { (Poszyt, j. pol., k. 86) }\end{array}$ & $1931-1933$ \\
\hline 174 & $\begin{array}{l}\text { Dowody do rachunków szpitala św. Jerzego w Lubawie. } \\
\text { (Poszyt, j. pol., k. 18) }\end{array}$ & 1935 \\
\hline 175 & $\begin{array}{l}\text { Rachunek z administracji majątku szpitala św. Jerzego w Grabowie. } \\
\text { (Poszyt, j. pol., k. 6) }\end{array}$ & $1924-1926$ \\
\hline \multirow[t]{2}{*}{176} & $\begin{array}{l}\text { St. Georgen-Hospital zu Loebau (Klostergut Grabau). Process mit dem Besitzer } \\
\text { Maximilian Liegmann aus Rosenthal. } \\
\text { (Poszyt, j. niem., k. 5) }\end{array}$ & 1914 \\
\hline & XII. Fundacje - legaty & \\
\hline 177 & $\begin{array}{l}\text { Index missarum, quae ex legatis vel ex fundatione in ecclesia Lubaviensi celebrari } \\
\text { debent. (Tabela mszy św. fundacyjnych } 48 \times 63 \mathrm{~cm} \text {, j. łac.) }\end{array}$ & ok. 1898 \\
\hline 178 & Stiftungen (Urkunden). (Teczka, j. łac., niem., k. 250) & $1845-1919$ \\
\hline 179 & $\begin{array}{l}\text { Leokadia Biber'sche Stiftung bei der St. Barbara-Kirche in Loebau. } \\
\text { (Poszyt, j. niem., k. 17; registr. B7) }\end{array}$ & $1897-1898$ \\
\hline 180 & Bielnicka'sche Stiftungen. (Poszyt, j. niem., k. 40) & 1905-1916 \\
\hline 181 & Victoria Ciechanowski'sche Stiftung. (Poszyt, j. niem., k. 15; registr. C1) & $1871-1874$ \\
\hline 182 & $\begin{array}{l}\text { Elisabeth Dias'sche Stiftung bei der Pfarrkirche zu Loebau. } \\
\text { (Poszyt, j. niem., k. 26; registr. D4) }\end{array}$ & $1892-1900$ \\
\hline 183 & $\begin{array}{l}\text { Anton und Catharina Dobrzyński'sche Stiftung. } \\
\text { (Poszyt, j. niem., k. 54; registr. D1). }\end{array}$ & $1859-1875$ \\
\hline 184 & Catharina Drążkiewicz’sche Stiftung. (Poszyt, j. niem., k. 5; registr. D3) & $1867-1868$ \\
\hline 185 & Catharina Figier'sche Stiftung. (Poszyt, j. niem., k. 47; registr. F2) & $1852-1898$ \\
\hline 186 & Vicar Cyrill Goldon'sche Stiftung von 600 M. (Poszyt, j. niem., k. 11; registr. G32) & $1884-1890$ \\
\hline 187 & Mathias Han'sche Stiftung in Loebau. (Poszyt, j. niem., k. 10; registr. H1) & 1849 \\
\hline 188 & $\begin{array}{l}\text { Emerit. Pfarrer Josephus Hillar'sche Stiftung (für das Krankenhaus der Barmherzigen } \\
\text { Schwester im Kloster Loebau). (Poszyt, j. niem., k. 14; registr. H4) }\end{array}$ & $1899-1907$ \\
\hline 189 & Catharina Jackowski'sche Stiftung. (Poszyt, j. niem., k. 33; registr. J3) & $1863-1879$ \\
\hline 190 & $\begin{array}{l}\text { Michael und Marianna Jaworowski'sche Stiftung. } \\
\text { (Poszyt, j. niem., k. 29; registr. J2) }\end{array}$ & $1860-1866$ \\
\hline
\end{tabular}




\begin{tabular}{|c|c|c|}
\hline Sygn. & Tytuł jednostki & Daty \\
\hline 191 & $\begin{array}{l}\text { Augustin und Theresia Jurgiewicz'sche Stiftung. } \\
\text { (Poszyt, j. niem., pol., k. 13; registr. J1) }\end{array}$ & $1848-1984$ \\
\hline 192 & Marianna Kadłubowska’sche Stiftung. (Poszyt, j. niem., k. 12; registr. K17) & $1898-1902$ \\
\hline 193 & Rochus v. Kuczkowski'sche Stiftung. (Poszyt, j. niem., k. 8; registr. K8) & 1891 \\
\hline 194 & Dr. Christoph Kupner'sche Stiftungen. (Poszyt, j. niem., k. 72; registr. K1) & $1809-1873$ \\
\hline 195 & Paul und Marianna Kurzyński'sche Stiftung. (Posz., j. niem., k. 33; registr. K5) & $1864-1873$ \\
\hline 196 & $\begin{array}{l}\text { Pfarrer (Joseph) Mania'sche Stiftung Grabes-Unterhaltungs-Stiftung und Armen- } \\
\text {-Unterstützung. (Poszyt, j. niem., k. 10; registr. M7) }\end{array}$ & 1896 \\
\hline 197 & Ferdinand Marschall'sche Stiftung. (Poszyt, j. niem., k. 18; registr. M3) & $1871-1872$ \\
\hline 198 & $\begin{array}{l}\text { Casimir und Catharina geb. Graduszewska Misterski'sche Stiftung. } \\
\text { (Poszyt, j. niem., k. 20; registr. M1) }\end{array}$ & $1862-1878$ \\
\hline 199 & Franz Osmański’sche Stiftung. (Poszyt, j. niem., k. 36) & $1859-1871$ \\
\hline 200 & Simon und Marianna Osmański'sche Stiftung. (Poszyt, j. niem., k. 15; registr. 02) & $1853-1870$ \\
\hline 201 & Marianna Pałkowska'sche Stiftung. (Poszyt, j. niem., k. 18; registr. P4) & $1887-1894$ \\
\hline 202 & (Anton) v. Pląskowski'sche Stiftung. (Poszyt, j. niem., k. 22; registr. P3) & $1856-1878$ \\
\hline 203 & $\begin{array}{l}\text { Rechnung über die Vermögens-Verwaltung der Pfarrer Michael von Pomierski'sche } \\
\text { Stiftung zum Unterhalte von Studierenden. (Teczka, składki 3, j. niem., k. 31) }\end{array}$ & $1892-1896$ \\
\hline 204 & $\begin{array}{l}\text { Thomas v. Prątnicki'sche Stiftung. } \\
\text { (Poszyt, j. niem., k. 34; registr. P1, por. sygn. 130) }\end{array}$ & $1807-1896$ \\
\hline 205 & $\begin{array}{l}\text { Acta betr. das zu Pfarrbauten verwendete Fundations-Kapital von } 1666 \text { Thal. } 20 \text { Sgr. } \\
\text { aus der Thomas Prątnicki'sche Stiftung. } \\
\text { (Poszyt, j. niem., k. 46; registr. P1", por. sygn. 130) }\end{array}$ & $1845-1854$ \\
\hline 206 & Pfarrer Rochon'sche Stiftung. (Poszyt, j. niem., k.19; registr. R2) & $1971-1874$ \\
\hline 207 & Anna Roznerska'sche Stiftung. (Poszyt, j. niem., k. 55; registr. R4) & $1848-1853$ \\
\hline 208 & Anton Rutecki’sche alias Ziółkowski Stiftung. (Poszyt, j. niem., k. 10; registr. R16) & $1903-1904$ \\
\hline 209 & $\begin{array}{l}\text { Domkapitular (Johannes David) Sartowski'sche Stiftung: a/ bei der Pfarrkirche; } \\
\text { b/ bei dem St. Georgs-Hospitale. (Poszyt, j. niem., k. 14; registr. S15) }\end{array}$ & $1899-1909$ \\
\hline 210 & Johann Schulz'sche Stiftung. (Poszyt, j. niem., k. 13; registr. S5) & $1888-1889$ \\
\hline 211 & Fräulein Veronika v. Turzyński'sche Stiftung. (Poszyt, j. niem., k. 24; registr. T5) & $1899-1905$ \\
\hline 212 & $\begin{array}{l}\text { Johann und Petronella Typtanowski'sche Stiftung. } \\
\text { (Poszyt, j. niem., k. 30; registr. T2) }\end{array}$ & $1869-1887$ \\
\hline 213 & $\begin{array}{l}\text { Acta des kathol. Kirchenvorstandes Loebau betr. das Probst Michael Wagner'sche } \\
\text { Legat von } 3000 \text { Mark. (Poszyt, j. pol., niem., k. 24; registr. W6) }\end{array}$ & $1887-1888$ \\
\hline 214 & Marianna Wilemska'sche Stiftung. (Poszyt, j. niem., k. 14; registr. W1) & $1883-1884$ \\
\hline 215 & Marianna v. Wodzińska'sche Stiftung. (Poszyt, j. niem., k. 68; registr. W5) & $1894-1897$ \\
\hline 216 & $\begin{array}{l}\text { Pfarrer Johann Zieliński'sche Meß-Fundation } 200 \text { Rth. } \\
\text { (Poszyt, j. pol., niem., k. 38; registr. Z9) }\end{array}$ & $1845-1903$ \\
\hline
\end{tabular}




\begin{tabular}{|c|c|c|}
\hline Sygn. & Tytuł jednostki & Daty \\
\hline 217 & $\begin{array}{l}\text { Acta betr. } 200 \text { Th. aus der Johann Zieliński'sche und } 100 \text { Rth. aus der August } \\
\text { Jurgiewicz'sche Stiftung ausgethan auf dem Liedtke'sche, nachher Haack'sche } \\
\text { Grundstück in Rumian № } 4 \text {. (Poszyt, j. niem., k. 16; registr. Z8) }\end{array}$ & $1858-1865$ \\
\hline 218 & Anton Żmudziński'sche Stiftung. (Poszyt, j. niem., k. 18; registr. Z26) & $1904-1905$ \\
\hline 219 & Marianna Żuchowska’sche Stiftung. (Poszyt, j. niem., k. 12; registr. Z10) & $1874-1875$ \\
\hline 220 & $\begin{array}{l}\text { Fundacje (Stiftungen): 1. Anna Kałczyńska, 2. Wincenty Wodziński, 3. Marianna } \\
\text { Combrowska, 4. Barbara Olszewska, 5. Anna Erdmańska. } \\
\text { (Poszyt, j. niem., pol., k. 59) }\end{array}$ & $1803-1903$ \\
\hline 221 & $\begin{array}{l}\text { Fundacje (Stiftungen): 1. Marianna Kijora, 2. Marianna Schmidt, 3. Elżbieta Koźmiń- } \\
\text { ska, 4. Marianna Kroplewska, 5. Wojciech Józefowicz, 6. Antoni i Józefina Dobrzyń- } \\
\text { scy, 7. Antoni Kijora, 8. Katarzyna Wilemska. (Poszyt, j. niem., pol., k. 72) }\end{array}$ & $1893-1905$ \\
\hline 222 & $\begin{array}{l}\text { Verschiedene Fundations-Kapitalien wie sie ehemals elocirt gewesen. } \\
\text { (Poszyt, j. niem., k. 63; sygn. registr. F1) }\end{array}$ & $1823-1887$ \\
\hline 223 & $\begin{array}{l}\text { Acta betr. } 16 \text { Thal. } 20 \text { Sgr. Fundations-Kapital, welche bis zum Jahre } 1844 \text { unbekannt } \\
\text { geblieben waren (...) gehörig zu den Fundations-Kapitalien ex variis fundationibus. } \\
\text { (Posz., j. niem., k. 8) }\end{array}$ & $1844-1845$ \\
\hline 224 & Fundationen und Reductionen. (Poszyt, j. niem., k. 142; registr. R9) & $1842-1914$ \\
\hline 225 & $\begin{array}{l}\text { Ein Stiftungs-Kapital von } 16 \text { Thal. } 20 \text { Sgr. und eine Rente von } 20 \text { Sgr. jährlich ein- } \\
\text { getragen auf dem Apothekengrundstück Loebau Nr. } 10 \text { betr. } \\
\text { (Poszyt, j. niem., k. 8; registr. K13) }\end{array}$ & $1842-1886$ \\
\hline 226 & $\begin{array}{l}\text { Die Austhuung von } 600 \text { Thal. aus der Kasse der hiesigen Rosenkranz-Bruderschaft } \\
\text { und } 50 \text { Thal. aus der Simon und Marianna Osmański'sche Stiftung zu Ztotowo, } 150 \\
\text { Thal. aus Vivtoria Ciechanowska'sche Stiftung, zusammen } 900 \text { Thal. auf d. Grund- } \\
\text { stück Rumian N. 26. (Poszyt, j. niem., k 93; registr. R3) }\end{array}$ & $1861-1872$ \\
\hline 227 & $\begin{array}{l}\text { Die Ausleihung von } 200 \text { Thal. des S. Valentin-Hospitals, } 100 \text { Thal. der Rosen- } \\
\text { kranz-Bruderschaft auf das Grundstück Loebau No } 269 \text { der Franz und Julianna } \\
\text { Dombrowski'sche Eheleute. (Poszyt, j. niem., k. 69; registr. V7) }\end{array}$ & $1861-1887$ \\
\hline 228 & $\begin{array}{l}\text { Ausleihung eines Kirchenstiftungs-Kapitals an den Lehrer Idzikowski und hypotheka- } \\
\text { rische Eintragung auf Loebau 39. (Poszyt, j. niem., k. 25; registr. 14) }\end{array}$ & $1845-1881$ \\
\hline 229 & $\begin{array}{l}\text { Ausleihung } 1600 \text { M. Pfand...Kapitalien auf dem Grundstück Londzyn N. } 26 \text { des } \\
\text { Ignaz Lewalski. (Poszyt, j. niem., k 37; registr. L4) }\end{array}$ & $1880-1892$ \\
\hline 230 & $\begin{array}{l}\text { Starsze etaty: Pfarrer v. Pomierski'sche Studien-Stiftung (1902-1907), Lipy (1897- } \\
\text {-1910), St. Valentin-Hospital (1900-1909), Rosenkranz-Bruderschaft (1902-1907). } \\
\text { (Poszyt, j. niem., k. 30) }\end{array}$ & $1897-1910$ \\
\hline 231 & $\begin{array}{l}\text { Rechnungen über die Verwaltung des Stiftungs-Vermögens. } \\
\text { (Poszyt, j. niem., k. 24; registr. R1) }\end{array}$ & $1854-1890$ \\
\hline 232 & $\begin{array}{l}\text { Rechnung über die Verwaltung des bei der kathol. Pfarr-Kirche zu Loebau (...) } \\
\text { vorhandenen Stiftungs-Vermögens. (Teczka, składki 15, j. niem., k. 121) }\end{array}$ & 1853-1869 \\
\hline 233 & $\begin{array}{l}\text { Rechnung über die Verwaltung des bei der kathol. Pfarr-Kirche zu Loebau vorhan- } \\
\text { denen Stiftungs-Vermögens. (Teczka, składki 18, j. niem., k. 180) }\end{array}$ & $1870-1890$ \\
\hline 234 & $\begin{array}{l}\text { Rechnung über die Verwaltung des der kathol. Pfarr-Kirche zu Loebau vorhandenen } \\
\text { Stiftungs-Vermögens. (Teczka, skł. } 7 \text {, j. niem., k. 97) }\end{array}$ & 1891-1901 \\
\hline
\end{tabular}




\begin{tabular}{|c|c|c|}
\hline Sygn. & Tytuł jednostki & Daty \\
\hline 235 & $\begin{array}{l}\text { Stiftungsrechnungen 1902-1912. (Rechnung über die Verwaltung des bei der kathol. } \\
\text { Pfarr-Kirche zu Leobau vorhandenen Stiftungs-Vermögens. } \\
\text { (Poszyt, j. niem., k. 166) }\end{array}$ & $1902-1912$ \\
\hline 236 & $\begin{array}{l}\text { Beläge zur Rechnung über die Verwaltung der bei der Pfarrkirche zu Loebau vorhan- } \\
\text { denen Stiftungs-Vermögens. (Poszyt, j. niem., k. 12) }\end{array}$ & 1862 \\
\hline 237 & $\begin{array}{l}\text { Beläge zur Rechnung über die Verwaltung des bei der kathol. Pfarrkirche zu Loebau/ } \\
\text { Westpr. Vorhandenen Stiftungs-Vermögens. (Poszyt, j. niem., k. 50) }\end{array}$ & 1901 \\
\hline 238 & Beläge zur Stiftungsrechnung. (Poszyt, j. niem., k. 29) & $1910-1914$ \\
\hline 239 & Beläge zur Stiftungsrechnung. (Poszyt, j. niem., k. 6) & 1915 \\
\hline \multirow[t]{3}{*}{240} & Beläge zur Stiftungsrechnung. (Poszyt, j. niem., k. 6) & 1917 \\
\hline & XIII. Sprawy gospodarczo-finansowe & \\
\hline & a/ Ogólne & \\
\hline 241 & Etats-Anfertigung. (Poszyt, j. niem., k. 175; registr. E7) & $1820-1911$ \\
\hline 242 & $\begin{array}{l}\text { Die Revision und Decharge der jährlichen Rechnungen der Pfarrkiche zu Loebau. } \\
\text { (Poszyt, j. niem., k. 356; registr. R13) }\end{array}$ & $1842-1895$ \\
\hline 243 & Cautions-Documente. (Teczka, j. niem., k. 34) & $1880-1897$ \\
\hline 244 & $\begin{array}{l}\text { Wertpapiere und Documente: I. Pfarrdotation; II. Stiftungen. } \\
\text { (Teczka, j. niem., k. 122) }\end{array}$ & $1884-1918$ \\
\hline 245 & Papiery wartościowe, obligacje. (Teczka, luzy, j. pol., k. 45) & $1924-1935$ \\
\hline 246 & Einkommen-Steuer. (Poszyt, j. niem., k. 48; registr. S13) & $1851-1914$ \\
\hline 247 & $\begin{array}{l}\text { Die Umlagen der Kirchen-Steuer für Loebau und Złotowo. } \\
\text { (Poszyt, j. niem., k. 32; registr. U3) }\end{array}$ & $1901-1908$ \\
\hline 248 & Podatek kościelny (Kirchensteuer). (Poszyt, j niem., pol., k. 248; registr. S20) & $1912-1922$ \\
\hline 249 & Steuer-Reklamationen. (Poszyt, j. niem., k. 158) & $1896-1903$ \\
\hline 250 & Das Deputatholz. (Poszyt, j. niem., k. 137; registr. D9) & $1844-1892$ \\
\hline 251 & Dezem-Getreide. (Poszyt, j. niem., k. 221; registr. D5) & $1850-1884$ \\
\hline 252 & Natural-Dezem-Ablösung aus Mortung. (Poszyt, j. niem., k. 57; registr. M5) & $1837-1880$ \\
\hline 253 & $\begin{array}{l}\text { Die Ablösung der Entschädigung für Messwein um Beitrag zum Organistegehalt. } \\
\text { (Poszyt, j. niem., k. 47) }\end{array}$ & $1800-1912$ \\
\hline 254 & $\begin{array}{l}\text { Die Ablösung der Stolgebühren in der kathol. Kirchengemeinde zu Loebau. } \\
\text { (Poszyt, j. niem., k. 19; registr. A7) }\end{array}$ & $1891-1893$ \\
\hline 255 & Ablösung etc. (Poszyt, j. niem., k. 61) & $1874-1879$ \\
\hline 256 & $\begin{array}{l}\text { Die Bestellung der bei Ablösung der Reallasten zu beachtenden Normalpreise und } \\
\text { Normal-Marktorte. (Poszyt, j. niem., k. 25; sygn. registr. R8) }\end{array}$ & 1850 \\
\hline 257 & $\begin{array}{l}\text { Rezessse: 1. Grabau, Altaristengrundstück, BI. 13; 2. Löbau, Amtsvorwerke; } 3 . \\
\text { Domänen-Vorwarke Bischwalde und Tinnwalde; 4. Forsterrevier Górzno. } \\
\text { (Poszyt, j. niem., k. 60) }\end{array}$ & $1874-1879$ \\
\hline 258 & $\begin{array}{l}\text { Rezess betr. die Ablösung der Reallasten von Loebau und Mortung. } \\
\text { (Poszyt, j. niem., k. 26) }\end{array}$ & $1880-1881$ \\
\hline
\end{tabular}




\begin{tabular}{|c|c|c|}
\hline Sygn. & Tytuł jednostki & Daty \\
\hline 259 & $\begin{array}{l}\text { Rezess betr. die Ablösung des auf dem Grundstück № } 216 \text { Loebau, Kreis Leobau, } \\
\text { für die katholische Pfarre zu Loebau haftenden Grundzinses L. } 576 . \\
\text { (Poszyt, j. niem., k. 10) }\end{array}$ & 1883 \\
\hline 260 & $\begin{array}{l}\text { Reces: Lubawa i Losy. (Rezess betr., die Ablösung der auf einigen Grundstücken zu } \\
\text { Loebau und Lossen für das St. Georgs-Hospital und die kathol. Pfarre und Kirche } \\
\text { zu Loebau haftenden Reallasten L. 714). (Poszyt, j. niem., k. 17) }\end{array}$ & 1885 \\
\hline 261 & $\begin{array}{l}\text { Acta betr. } 40 \text { Thaler Kirchengelds ausgeliehenen a. Hyp. L. } 222 . \\
\text { (Poszyt, j. niem., k. 45) }\end{array}$ & $1833-1868$ \\
\hline 262 & $\begin{array}{l}\text { Aufnahme eines Darlehns aus der Königl. Provinzialhilfe-Kasse in Königsberg Pr. } \\
\text { (Poszyt, j. niem., k. 168; registr. D8) }\end{array}$ & $1870-1889$ \\
\hline 263 & $\begin{array}{l}\text { Abgaben zum kirchlichen Baufonds der Diöcese Culm und Diözesanbedürfnisfond. } \\
\text { (Poszyt, j. niem., k. 13; registr. A10) }\end{array}$ & $1904-1909$ \\
\hline 264 & $\begin{array}{l}\text { Sparkassenbuch der Sparkasse des Kreises Loebau. Katholische Kirche (Scheune- } \\
\text {-Baufonds) Loebau. (Książeczka bankowa, j. niem., pol., k. 20) }\end{array}$ & $1896-1929$ \\
\hline \multirow[t]{2}{*}{265} & Opłaty za ławki. (Poszyt, j. pol., k. 33) & $1925-1927$ \\
\hline & b/ Ziemia kościelna & \\
\hline 266 & Verpachtung der Pfarrhufen zu Loebau. (Poszyt, j. niem., k. 31) & $1844-1847$ \\
\hline 267 & Verpachtung der Pfarrhufen. (Poszyt, j. niem., k. 151; registr. P10) & $1866-1903$ \\
\hline 268 & $\begin{array}{l}\text { Umowy dotyczace wydzierżawienia ziemi kościelnej. } \\
\text { (Teczka, składki 20, j. pol., k. 108) }\end{array}$ & 1938 \\
\hline 269 & $\begin{array}{l}\text { Ankauf des Grundstückes Löbau } 56 \text { zur Anlage eines Pfarrgartens resp. Stiftung. } \\
\text { (Poszyt, j. niem., k 60; registr. G51) }\end{array}$ & $1840-1882$ \\
\hline 270 & $\begin{array}{l}\text { Pfarrgarten Loebau № } 218 \text { (auf der Grabauer Vorstadt). } \\
\text { (Poszyt, j. niem., k. 102; registr. P9) }\end{array}$ & $1855-1893$ \\
\hline 271 & $\begin{array}{l}\text { Das Mühlengrundstück Loebau № } 216 \text { auf Pfarrgrund stehend. } \\
\text { (Poszyt, j. niem., k. 53; registr. L6) }\end{array}$ & $1859-1883$ \\
\hline 272 & $\begin{array}{l}\text { Die auf dem Grundstück Złotowo № } 64 \text { ausstehenden Kapitalien. } \\
\text { (Poszyt, j. niem., k. 46) }\end{array}$ & $1822-1888$ \\
\hline 273 & $\begin{array}{l}\text { Die Summe jährlich } 34 \text { M. aus dem Grundstücke Lossen Nr. } 7 . \\
\text { (Poszyt, j. niem., k. 33; registr. L1) }\end{array}$ & $1842-1886$ \\
\hline 274 & Die Altaristen Grundstücke in Grabau. (Poszyt, j. niem., k. 328; registr. A5) & $1827-1883$ \\
\hline \multirow[t]{2}{*}{275} & Altaristen von Grabau. (Poszyt, j. niem., k. 90; sygn. registr. A4) & $1857-1901$ \\
\hline & c/ Akta kasowe & \\
\hline 276 & $\begin{array}{l}\text { Księga przychodu i rozchodu kasy kościoła farnego lubawskiego. Regestra percep- } \\
\text { tarum ecclesiae Archipresbyteralis Lubaviensis (...). Regestra expensarum Ecclesiae } \\
\text { Archipresbyteralis Lubaviensis (...). (Księga, j. łac., pol., k. 406) }\end{array}$ & $1760-1851$ \\
\hline 277 & $\begin{array}{l}\text { Einnahmen der kathol. Pfarrkirchenkasse zu Loebau vom } 1861 \text { bis } 1873 \text {. Ausgaben } \\
\text { der kathol. Pfarrkichenkasse zu Loebau. (Księga, j. niem., k. 127) }\end{array}$ & $1861-1873$ \\
\hline 278 & Ausgabe-Journal der Pfarre Loebau. (Księga, j. niem., k. 271) & $1876-1911$ \\
\hline 279 & Einnahme-Journal der Pfarre Loebau. (Księga, j. niem., k. 290) & 1891-1911 \\
\hline
\end{tabular}




\begin{tabular}{|c|c|c|}
\hline Sygn. & Tytuł jednostki & Daty \\
\hline 280 & Einnahme-Journal. (Księga, j. niem., pol., k. 261) & $1902-1911$ \\
\hline 281 & Księga kasowa. Begräbnisse und Trauungen. (Księga, j. niem., pol., k. 289) & 1913-1917 \\
\hline 282 & $\begin{array}{l}\text { Kirchenkase. Einnahme-Journal. Dziennik dochodów (wpływów) kasy kościelnej } \\
\text { kościoła katol. w Lubawie. (Księga, j. pol., niem., k. 102) }\end{array}$ & 1924-1942 \\
\hline 283 & Księga dochodów i rozchodów. (Księga, j. niem., pol., s. 384) & 1943-1972 \\
\hline 284 & $\begin{array}{l}\text { Księga kościelna. Kasa budowlana. Konto Kurii Biskupiej. Kasa bracka. Kasa cmen- } \\
\text { tarna. (Księga, j. niem., pol., k. 48) }\end{array}$ & $1942-1947$ \\
\hline 285 & $\begin{array}{l}\text { Kasa kościelna w Lubawie. Dziennik przychodów i rozchodów kasy kościelnej } \\
\text { kościoła katol. w Lubawie.(Księga, j. pol., k. 100) }\end{array}$ & $1948-1962$ \\
\hline 286 & $\begin{array}{l}\text { Rechnung von Einnahmen und Ausgaben der Pfarr-Kichen-Kasse zu Loebau (nebst } \\
\text { Inventarium). (Teczka, } 10 \text { składek, j. niem., k. 106) }\end{array}$ & $1815-1825$ \\
\hline 287 & $\begin{array}{l}\text { Rechnung von Einnahmen und Ausgaben der Pfarr-Kirchen-Kasse (nebst Inven- } \\
\text { tarium). (Teczka, składki 11, j. niem., k. 146) }\end{array}$ & $1826-1835$ \\
\hline 288 & $\begin{array}{l}\text { Jahres-Rechnung der kathol. Kirchen-Kasse (nebst Inventarium). } \\
\text { (Teczka, składki 11, j. niem., k. 114) }\end{array}$ & $1836-1850$ \\
\hline 289 & $\begin{array}{l}\text { Rechnung über die Vermögens-Verwaltung der kath. Pfarrkirche der hl. Anna zu } \\
\text { Loebau (nebst Inventarium). (Teczka, składki 10, j. niem., k. 139) }\end{array}$ & $1851-1860$ \\
\hline 290 & $\begin{array}{l}\text { Rechnung über die Vermögens-Verwaltung (nebst Inventarium). } \\
\text { (Teczka, składki 8, j. niem., k. 114) }\end{array}$ & $1861-1869$ \\
\hline 291 & $\begin{array}{l}\text { Rechnung über die Vermögens-Verwaltung (nebst Inventarium). } \\
\text { (Teczka, składki 11, j. niem., k. 232) }\end{array}$ & $1870-1880$ \\
\hline 292 & $\begin{array}{l}\text { Rechnung über die Vermögens-Verwaltung (nebst Inventarium). } \\
\text { (Teczka, składki 9, j. niem., k 112) }\end{array}$ & $1880-1890$ \\
\hline 293 & $\begin{array}{l}\text { Rechnung über die Vermögens-Verwaltung (nebst Inventarium). } \\
\text { (Teczka, składki 8, j. niem., k. 171) }\end{array}$ & $1891-1902$ \\
\hline 294 & $\begin{array}{l}\text { Rechnung über die Vermögens-Verwaltung (nebst Inventarium). } \\
\text { (Poszyt, j. niem., k. 206) }\end{array}$ & $1903-1912$ \\
\hline 295 & $\begin{array}{l}\text { Beläge zur Kirchen-Kasse-Rechnung der kathol. Pfarrkirche zu Loebau pro } 1844 . \\
\text { (Poszyt, j. niem., k. 38) }\end{array}$ & $1844-1845$ \\
\hline 296 & $\begin{array}{l}\text { Beläge zur Rechnung über die Vermögens-Verwaltung der kath. Pfarrkirche pro } 1862 . \\
\text { (Poszyt, j. niem., k. 41) }\end{array}$ & $1862-1864$ \\
\hline 297 & Beläge zur Rechnung... pro 1902. (Poszyt, j. niem., k. 57) & 1902 \\
\hline 298 & Beläge zur Rechnung... pro 1903. (Poszyt, j. niem., k. 72) & 1903-1904 \\
\hline 299 & Beläge... pro 1904. (Poszyt, j. niem., k. 52) & 1904 \\
\hline 300 & Beläge... pro 1905. (Poszyt, j. niem., k. 54) & 1905 \\
\hline 301 & Beläge... pro 1906. (Poszyt, j. niem., k. 50) & 1906 \\
\hline 302 & Beläge... pro 1907. (Poszyt, j. niem., k. 53) & 1907 \\
\hline 303 & Beläge... pro 1908 (Poszyt, j. niem., k. 54) & 1908 \\
\hline 304 & Beläge... pro 1909 (Poszyt, j. niem., k. 59) & 1909 \\
\hline
\end{tabular}




\begin{tabular}{|c|c|c|}
\hline Sygn. & Tytuł jednostki & Daty \\
\hline 305 & Beläge... pro 1915. (Poszyt, j. niem., k. 51) & 1914-1916 \\
\hline 306 & Beläge... für das Jahr 1917-1918. (Poszyt, j. niem., k. 75) & $1916-1918$ \\
\hline 307 & Dowody do rachunków kościelnych. (Poszyt, j. pol., k. 55) & $1926-1927$ \\
\hline 308 & $\begin{array}{l}\text { Dowody do rachunków kościelnych za r. } 1930 . \\
\text { (Poszyt, j. pol., k. 47) }\end{array}$ & 1930 \\
\hline 309 & Dowody do rachunków... za r. 1931 i 1933. (Poszyt, j. pol., k. 161) & $1931-1933$ \\
\hline 310 & Dowody do rachunków... za r. 1932. (Poszyt, j. pol., k. 80) & 1932 \\
\hline 311 & Dowody do rachunków... za r. 1934. (Poszyt, j. pol., k. 57) & $1934-1935$ \\
\hline 312 & Dowody do rachunków... za r. 1937. (Poszyt, j. pol., k. 81) & $1937-1938$ \\
\hline 313 & Dowody do rachunków... za r. 1938. (Poszyt, j. pol., k. 26) & 1938 \\
\hline 314 & Dowody do Kasy A 1932. (Poszyt, j. pol., k. 76) & 1932 \\
\hline 315 & Dowody do rachunku Kasy A. (Poszyt, j. pol., k. 102) & $1931-1933$ \\
\hline \multirow[t]{2}{*}{316} & Dowody do Kasy A 1935. (Poszyt, j. pol., k....) & 1934-1935 \\
\hline & XIV. Sprawy sporne i procesy & \\
\hline 317 & $\begin{array}{l}\text { Acta betr. die Auseinandersetzung zwischen den Mathias Tyblewski'schen Erben und } \\
\text { dem Pfarrer Anton Klingenberg in Loebau. Vol. I. (Poszyt, j. niem., k. 71) }\end{array}$ & $1836-1860$ \\
\hline 318 & $\begin{array}{l}\text { Acta betr. die Auseinandersetzung zwischen den Mathias Tyblewski'schen Erben und } \\
\text { dem Pfarrer Anton Klingenberg in Loebau. Vol. II. (Poszyt, j. niem., k. 160) }\end{array}$ & $1843-1852$ \\
\hline 319 & $\begin{array}{l}\text { Acta des Pfarrers Klingenberg betr. die Auseinandersetzung mit den Tyblewski'schen } \\
\text { Erben wegen des Dezem-Getreides von Tynwalde pro } 1843 . \\
\text { (Poszyt, j. niem., k. 32; registr. T3) }\end{array}$ & $1843-1903$ \\
\hline 320 & $\begin{array}{l}\text { Prozess der Pfarre gegen den Müller August Müller wegen c. } 3 \text { Morgen Pfarrland. } \\
\text { (Poszyt, j. niem., k. 215; registr. L2) }\end{array}$ & $1843-1872$ \\
\hline 321 & $\begin{array}{l}\text { Acta manualia des Rechtsanwalts und Notars Raue zu Löbau in Sachen der katholi- } \\
\text { schen Pfarre zu Löbau wider Müller wegen } 400 \text { Rthal. (Poszyt, j. niem., k. 98) }\end{array}$ & $1865-1870$ \\
\hline 322 & $\begin{array}{l}\text { Die Auseinandersetzung zwischen dem Domherrn Klingenberg und Pfarrer Lic. } \\
\text { Sartowski und dessen Nachfolger (Tradition). } \\
\text { (Poszyt., j. niem., k. 100; registr. T1) }\end{array}$ & 1869-1895 \\
\hline 323 & $\begin{array}{l}\text { Acta betr. die Lehrer[Wojciech] Golisch'sche (Pfarradministrator Bolesl. Golisch) - } \\
\text { Vacanz-Revenuen. Nachlassregulierung. (Poszyt, j. niem., k. 38) }\end{array}$ & 1896-1897 \\
\hline 324 & $\begin{array}{l}\text { Acta manualia der Testaments-Executoren betr. die Regulierung des Nachlasses des } \\
\text { verstorbenen Pfarrers Josef Mania. (Poszyt, j. niem., k. 45) }\end{array}$ & 1869 \\
\hline 325 & $\begin{array}{l}\text { Acta betr. den Nachlass des Karmeliten Balthasar Roznerski. } \\
\text { (Poszyt, j. niem., pol., k. 68) }\end{array}$ & 1873 \\
\hline 326 & $\begin{array}{l}\text { Acta des Dekans Sartowski in Loebau betr. den Nachlass des Fräulein Ludovica } \\
\text { Olszewska in Lautenburg. (Poszyt, j. niem., k. 22) }\end{array}$ & $1881-1890$ \\
\hline 327 & $\begin{array}{l}\text { Die Grenzstreitigkeiten der Pfarre mit A. Goldstand. } \\
\text { (Poszyt, j. niem., k. 173; registr. L5) }\end{array}$ & 1890-1893 \\
\hline 328 & Proces c/a ks. dr A. Okoniewski et consortes. (Poszyt, j. niem., k. 18) & 1907 \\
\hline
\end{tabular}




\begin{tabular}{|c|c|c|}
\hline Sygn. & Tytuł jednostki & Daty \\
\hline 329 & $\begin{array}{l}\text { Conversion von Paul Karkut und Zeugnisverweigerung. } \\
\text { (Poszyt, j. niem., pol., k. 45; registr. K) }\end{array}$ & $1905-1909$ \\
\hline 330 & $\begin{array}{l}\text { Acta der Pfarre Loebau betr. die zu Zuchthaus-Strafen verurteilten Individuen. (Poszyt, } \\
\text { j. niem., k. 167) }\end{array}$ & $1862-1898$ \\
\hline 331 & Strafsachen. (Poszyt, j. niem., k. 249) & 1904-1919 \\
\hline 332 & $\begin{array}{l}\text { Acta betr. den Prozess gegen Schüler der Gymnasien: Culm, Strasburg, Thorn. (Pro- } \\
\text { ces filomatów pomorskich. Wyrok sądowy, } 25 \text { IX 1901). (Poszyt, j. niem., k. 84) }\end{array}$ & 1901 \\
\hline 333 & $\begin{array}{l}\text { Politische Prozesse gegen Geistlichen. (Strajk szkolny w dekanacie lubawskim). } \\
\text { (Poszyt, j. niem., pol., k. 72) }\end{array}$ & $1897-1908$ \\
\hline 334 & $\begin{array}{l}\text { Georg Gottfried Kallenbach'sche Testament. Vol. I. } \\
\text { (Poszyt, j. niem., k. 440; registr. K14) }\end{array}$ & $1837-1880$ \\
\hline 335 & $\begin{array}{l}\text { Georg Gottfried Kallenbach'sche Testament. Vol. la. (Acta civilia des Königl. Kreis- } \\
\text {-Gerichts in Löbau). (Teczka, j. niem., k. 113; registr. K1) }\end{array}$ & $1850-1878$ \\
\hline 336 & G. G. Kallenbach'sche Nachlasssache. Vol. II. (Poszyt, j. niem., k. 93; registr. K2) & $1880-1884$ \\
\hline 337 & $\begin{array}{l}\text { Acta des Königl. Notars F. M. Burkart zu Bamberg die Verlassenschaft des Arche- } \\
\text { ologen Kallenbach Gottfried zu Bamberg betr. Vol. III. } \\
\text { (Poszyt, j. niem., k. 223; registr. K3) }\end{array}$ & $1865-1868$ \\
\hline 338 & $\begin{array}{l}\text { Ausgabe-Belege in der Verlassenschaft des Archeologen Gottfried Kallenbach von } \\
\text { Bamberg. (Poszyt, j. niem., k. 38) }\end{array}$ & $1848-1867$ \\
\hline \multirow[t]{4}{*}{330} & $\begin{array}{l}\text { Briefe von A. Görber zu Löbau an Archit. und Prof. lac. Schmitt - Friderich zu Bam- } \\
\text { berg. (Kallenbach'sche Verlassenschaft betr.). (Poszyt, j. niem., k. 21) }\end{array}$ & $1860-1865$ \\
\hline & Testament i sprawa archeologa G. G. Kallenbacha zob. także szpital św. Walentego & \\
\hline & XV. Kościół parafialny (filia Lubawy) w Złotowie & \\
\hline & a / Fundacje & \\
\hline 340 & $\begin{array}{l}\text { Acta der Pfarre Loebau betr. die Johann und Marianna Graduszewski'sche Stiftung } \\
\text { bei der Filial-Kirche zu Ztotow0. } \\
\text { (Poszyt, j. niem., k. 18; registr. G33) }\end{array}$ & 1879-1895 \\
\hline 341 & $\begin{array}{l}\text { Acta betr. die Anton und Gottliebe Graduszewski'sche Stiftung bei der Filialkirche zu } \\
\text { Złotowo. (Poszyt, j. niem., k. 14; registr. G35) }\end{array}$ & $1891-1893$ \\
\hline 342 & $\begin{array}{l}\text { Acta der Pfarrei Loebau betr. die Wilhelm Kikul'sche Stiftung von } 100 \text { Thal. bei der } \\
\text { Filialkirche in Ztotowo. (Poszyt, j. niem., k. 38; registr. K4) }\end{array}$ & $1871-1887$ \\
\hline 343 & $\begin{array}{l}\text { Acta der Filialkirche in Złotowo betr. die Marianna Kurlenda'sche Stiftung. } \\
\text { (Poszyt, j. niem., k. 15; registr. K7) }\end{array}$ & $1883-1897$ \\
\hline 344 & $\begin{array}{l}\text { Acta betr. die Joseph Orzechowski'sche Stiftung bei der kathol. Filial-Kirche zu } \\
\text { Złotowo. (Poszyt, j. niem., k. 19; registr. 04) }\end{array}$ & $1891-1894$ \\
\hline \multirow[t]{2}{*}{345} & $\begin{array}{l}\text { Rechnung über die Verwaltung des bei der kathol. Filial-Kirche zu Złotowo im Deca- } \\
\text { nate Loebau vorhandenen Stiftung-Vermögens. (Teczka, skł. 35, j. niem., k 180) }\end{array}$ & $1857-1906$ \\
\hline & b / Sprawozdania kasowe & \\
\hline 346 & $\begin{array}{l}\text { Jährliche-Kirchen-Rechnung der Filial-Kirche zu Złotowo. } \\
\text { (Poszyt, j. niem., k. 7) }\end{array}$ & $1803-1804$ \\
\hline
\end{tabular}




\begin{tabular}{|c|c|c|}
\hline Sygn. & Tytuł jednostki & Daty \\
\hline 347 & $\begin{array}{l}\text { (Jahres)-Rechnung von der Einnahme und Ausgabe bei der Filial-Kirchen-Kasse. } \\
\text { (Teczka, } 26 \text { składek, j. niem., k. 72) }\end{array}$ & $1815-1835$ \\
\hline 348 & $\begin{array}{l}\text { Jahres-Rechnung der kathol. Kirchen-Kasse der Filial-Kirche zu Złotowo. } \\
\text { (Teczka, } 15 \text { składek, k. 84) }\end{array}$ & $1836-1850$ \\
\hline 349 & $\begin{array}{l}\text { Rechnung über die Vermögens-Verwaltung der kathol. Filial-Kirche zu Złotowo. } \\
\text { (Teczka, } 9 \text { składek, j. niem., k. 107) }\end{array}$ & $1851-1858$ \\
\hline 350 & $\begin{array}{l}\text { Rechnung über die Vermögens-Verwaltung der kathol. Filial-Kirche der h. Barbara zu } \\
\text { Ztotowo. (Teczka, } 9 \text { skt., j. niem., k. 237) }\end{array}$ & $1860-1869$ \\
\hline 351 & $\begin{array}{l}\text { Rechnung über die Vermögens-Verwaltung der kathol. Filial-Kirche d.h. Barbara zu } \\
\text { Ztotowo. (Teczka, } 10 \text { skł., j. niem., k. 140) }\end{array}$ & $1870-1879$ \\
\hline 352 & $\begin{array}{l}\text { Rechnung über die Vermögens-Verwaltung der kathol. Filial-Kirche d.h. Barbara zu } \\
\text { Ztotowo. (Teczka,10 skł., j. niem., k. 106) }\end{array}$ & $1880-1899$ \\
\hline 353 & $\begin{array}{l}\text { Rechnung über die Vermögens-Verwaltung der kathol. Filial-Kirche zu Złotowo. } \\
\text { (Teczka, } 8 \text { składek, j. niem., k. 119) }\end{array}$ & $1890-1897$ \\
\hline \multirow[t]{2}{*}{354} & $\begin{array}{l}\text { Rechnung über die Vermögens-Verwaltung der kathol. Filial-Kirche zu Złotowo. } \\
\text { (Teczka, } 7 \text { składek, j. niem., k. 98) }\end{array}$ & $1900-1906$ \\
\hline & c/ Złotowo - akta procesowe & \\
\hline \multirow[t]{2}{*}{355} & $\begin{array}{l}\text { Proces Agnieszki Drulla przeciw ziemianinowi Franciszkowi Dembowskiemu w Zło- } \\
\text { towie } 03000 \text { M. (Poszyt, j. niem., k. 16) }\end{array}$ & \\
\hline & XVI. Varia & \\
\hline 356 & $\begin{array}{l}\text { Akten betreffend: 1. Kirchenstaat, Papst Pius IX. über die Emission eines verzinsli- } \\
\text { chen Anlehens 1860; 2. 50jähriges Priesterjubiläum; 3. Judentaufen; 4. Oeffentliche } \\
\text { Kreuze, Figuren etc.; 5. Teilnahme der Geistlichen am Diner am Kaisersgeburtstag. } \\
\text { (Poszyt, j. niem., pol., k. 75) }\end{array}$ & $1860-1906$ \\
\hline 357 & Die Beaufsichtigung minorenner Waisen. (Poszyt, j. niem., k. 148; registr. W9) & $1852-1905$ \\
\hline 358 & Acta der Pfarrkirche Loebau betreffend Cholera. (Poszyt, j. niem., k. 18) & $1855-1873$ \\
\hline 359 & $\begin{array}{l}\text { Acta... enthaltend Verschiedenes: 1. Aufruf: Weichselüberschwemmung 1855; } \\
\text { 2. Errichtung des Neustädter Gymnasiums; } 3 \text {. Aufruf: Bau der Kirche in Marienwerder } \\
\text { 1857; 4. Errichtung des Mariendenkmals in Pelplin 1857; 5. Aufruf: Kirche in Dt. } \\
\text { Eylau 1856, etc. (Poszyt, j. niem., pol., s. 367, k. 184) }\end{array}$ & $1816-1892$ \\
\hline 360 & Różne akta. (Teczka akt luźnych, j. niem., pol., k. 113) & $1842-1879$ \\
\hline 361 & $\begin{array}{l}\text { Lubawa. Mapy miasta i parafii, plany, projekty budowy i remontów kościoła oraz } \\
\text { Kaplicy Mortęskich, projekty plebanii i pomnika Chrystusa Króla. Konserwacja za- } \\
\text { bytków sztuki sakralnej. (Teka o wymiarach } 60 \text { x } 40 \mathrm{~cm} \text { zawierająca } 43 \text { załączniki } \\
\text { dokumentacji technicznej w j. niem. i pol.) }\end{array}$ & XIX-XX w. \\
\hline 365 & Por. sygn. 9a, 30a, 35a, 144a & \\
\hline
\end{tabular}

